University of Louisville

ThinkIR: The University of Louisville's Institutional Repository

Electronic Theses and Dissertations

$12-2010$

\title{
Postwar Sierra Leone : are programs of reconstruction addressing the causes of war?
}

Lovetta Anita Thompson 1985-

University of Louisville

Follow this and additional works at: https://ir.library.louisville.edu/etd

\section{Recommended Citation}

Thompson, Lovetta Anita 1985-, "Postwar Sierra Leone : are programs of reconstruction addressing the causes of war?" (2010). Electronic Theses and Dissertations. Paper 1437.

https://doi.org/10.18297/etd/1437

This Master's Thesis is brought to you for free and open access by ThinkIR: The University of Louisville's Institutional Repository. It has been accepted for inclusion in Electronic Theses and Dissertations by an authorized administrator of ThinkIR: The University of Louisville's Institutional Repository. This title appears here courtesy of the author, who has retained all other copyrights. For more information, please contact thinkir@louisville.edu. 
POSTWAR SIERRA LEONE: ARE PROGRAMS OF RECONSTRUCTION ADDRESSING THE CAUSES OF WAR?

\title{
By
}

Lovetta Anita Thompson

B.A., University of Kentucky, 2007

\author{
A Thesis \\ Submitted to the Faculty of the \\ College of Arts and Sciences of the University of Louisville \\ In Partial Fulfillment of the Requirements \\ for the Degree of
}

\author{
Master of Arts \\ Department of Pan-African Studies \\ University of Louisville \\ Louisville, Kentucky
}

December 2010 
Copyright 2010 by Lovetta Anita Thompson

All rights reserved 

POSTWAR SIERRA LEONE: ARE PROGRAMS OF RECONSTRUCTION ADDRESSING THE CAUSES OF WAR?

\section{By}

Lovetta Anita Thompson

B.A., University of Kentucky, 2007

A Thesis Approved on

June 10,2010

by the following Thesis Committee:

Thesis Director 


\section{DEDICATION}

This thesis is dedicated to my parents Dr. Bankole Thompson and

Dr. Adiatu Thompson who constantly pushed me to improve my head and mind through the educational opportunities they presented to me. 


\section{ACKNOWLEDGEMENTS}

I would like to thank my Thesis Advisor, Dr. Raphael Njoku, for his guidance and patience through this process. I would also like to thank the other committee members, Dr. Jennie Burnet and Dr. Denise Martin for their comments and assistance in this project. Additionally, I would like to thank my family and close friends who consistently encouraged me throughout this process, reminding me that failure is not an option. A special thank you to Jennifer Oladipo who provided an extra set of eyes to this work, and gave great feedback. Thank you to all that have brought out the best in me, and helped me to stick with it. Your kind words and actions are highly appreciated. 


\section{ABSTRACT \\ POSTWAR SIERRA LEONE: ARE PROGRAMS OF RECONSTRUCTION ADDRESSING THE CAUSES OF THE WAR?}

Lovetta A. Thompson

June 10,2010

This multilayered study is an appraisal of some of the ongoing post-conflict reconstruction efforts in Sierra Leone in light of the causes of the conflict, which lasted from 1991-2002. It begins by providing a critical examination of the historical antecedents leading up to the war. The problems of colonialism which brought together different nationalities under one political umbrella by force of arm, along with other motley of issues such as corrupt leadership and inter-ethnic violence led to the outbreak of war in 1991. Although different studies have discussed these factors, very few, if any, have tried to make a connection between causation and reconstruction with a view to find a lasting peace. The aim of the study, therefore, is to appraise the ongoing post-conflict reconstruction efforts in Sierra Leone in light of the causes of the conflict. No lasting peace will be achieved unless there are practical steps addressing the very structures that brought about the war. A central focus is to gain some insights on the successes and failures of the ongoing reconstruction programs. The findings of the study conclude that the post-conflict reconstruction efforts in Sierra Leone have been moderately successful at best. If basic needs such as educational and health care reform, as well as employment opportunities for youth are not met, Sierra Leone will continue to carry a cloud where conditions are still ripe for conflict. 
TABLE OF CONTENTS

PAGE

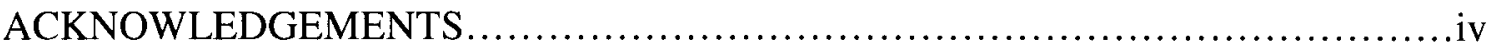

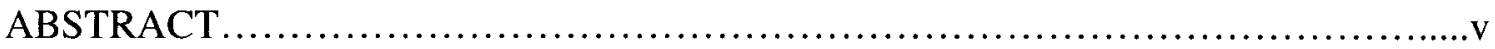

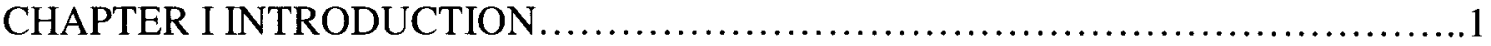

CHAPTER II HISTORICAL BACKGROUND .....................................12

CHAPTER III THEORIES ON THE CAUSES OF WAR ..............................30

CHAPTER IV CHALLENGES OF POSTWAR RECONSTRUCTION ..................43

CHAPTER V POSTWAR SIERRA LEONE: INSTITUTIONAL \& SOCIETAL

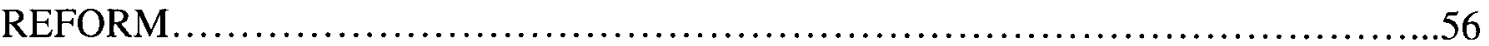

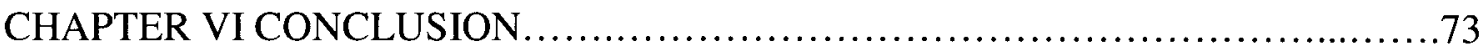

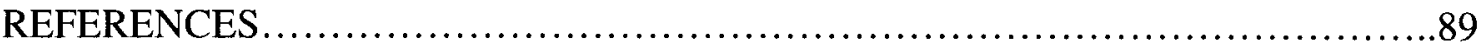

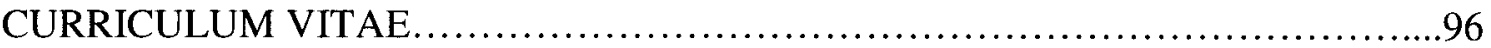




\section{CHAPTER I:}

\section{INTRODUCTION}

\section{Background and Purpose of Study}

This study examines the major post-conflict reconstruction efforts in Sierra Leone with a view to assess their successes and failures in light of the major factors that brought about the civil conflict lasting between 1991-2002. While there has been extensive research conducted on what caused the protracted violence in the country, very little is known about how effective the ongoing programs of reconstruction are addressing the causes in order for the country to not relapse into violence again. The study illustrates that avoiding renewed violence is one of the foremost tasks facing postwar reconstruction programs, organizations, politicians, and theorists. While the Reconciliation Commission on the war submitted in its 2004 Report that "bad governance, endemic corruption, and denial of basic human rights created deplorable conditions that made conflict inevitable," other causes such as issues pertaining to youth marginalization, which was also mentioned as one of the primary causes by the Truth and Reconciliation Commission, have remained largely neglected, particularly by the Sierra Leone government. ${ }^{2}$ Recently, United Nations Secretary-General Ban Ki-Moon, while lauding

\footnotetext{
${ }^{1}$ Final Report of the Sierra Leone Truth and Reconciliation Commission Volume. 1, October 2004, 10.

${ }^{2}$ Sierra Leone Truth and Reconciliation Commission Final Report: Volume 2 (October 2004), 30.
} 
the progress Sierra Leone has made within the past eight years, identifies the need to create opportunities for young people and improvements in education as crucial challenges that must be met. ${ }^{3}$ With that, this study takes the view that programs of reconstruction need to take into consideration all of the major causes of the conflict in order for lasting peace to be achieved. If all of these issues are not addressed in their entirety, there will always be a possibility for recurring violence--the such that for years threatened the very foundations of the country to reoccur.

In 1991, the small West African nation of Sierra Leone, located between Guinea and Liberia, was plunged into a brutal civil war that left an enduring legacy of political instability and economic devastation. It all began when on March 23, 1991, a group of approximately one hundred fighters comprising Sierra Leonean dissidents, Liberian fighters loyal to former President Charles Taylor of Liberia, and a small band of mercenaries from Burkina Faso invaded eastern Sierra Leone at Bomaru, Kailahun District. ${ }^{4}$ The group that called itself the Revolutionary United Front (RUF) advanced a vaguely populist agenda of fighting against the corrupt and inept government of President Joseph Momoh and his business associates in Freetown, the capital of Sierra Leone. ${ }^{5}$ Momoh had led a dubious regime that exploited the country of its natural resources for personal gains. With 2002 marking the end of the war, best remembered today as the "Diamond Conflict," it became necessary for the nation to address the residual effects of the war. Herein lays one justification for a study of this nature and scope.

\footnotetext{
${ }^{3}$ AllAfrica.com, "Sierra Leone: Ban Lauds Country's Advances in Firming Up Stability," June 15 2010, http://allafrica.com/stories/201006151292.html.

${ }^{4}$ John L. Hirsch, Sierra Leone: Diamonds and the Struggle for Democracy (Boulder: Lynne Reinner Publishers, Inc. 2001), 31.

${ }^{5}$ Sahr Kpundeh, Corruption and Political Insurgency (Dakar: CODESRIA 2004), 90-91.
} 
At the commencement of the attack on Bomaru in 1991, the RUF presented no concrete program of action or revolutionary agenda. Rather, prior to the assault, the RUF had circulated in Sierra Leone its so-called Basic Document, which contained a message that criticized the neo-colonialist character of the Momoh administration. Lacking a solid political platform, the rebel propaganda failed to attract meaningful support from the people of Sierra Leone. In an apparently desperate act of frustration, the RUF responded with indiscriminate violence against women, children, and at times, whole communities. ${ }^{6}$ This initial attack was the first among many that turned Sierra Leone into a lawless nation and thus, resulted in a coup led by the Armed Forces Revolutionary Council (AFRC). While the AFRC were opposed to the RUF, they did not necessarily support the ruling government. Rather, the rise of the AFRC quickly turned the conflict into three factions, as the Civil Defense Forces (CDF), a traditional militia banded together on the side of the government to restore democratic rule. The war continued for a decade, lasting until January 18, 2002.

Having quickly taken control of some of the diamond mines, the RUF became a major stakeholder in the conflict, and they sustained the war with profits from illegal mining of Sierra Leone's diamonds. Their utilization of diamonds-the most valuable natural resource in the country-for weapons trade and profit attracted much international attention to the processes of mining and the trading of diamonds. It should be noted, however, that some scholars have argued that diamonds were not the only

\footnotetext{
${ }^{6}$ Hirsch, Diamonds and the Struggle, 26; Kpundeh, Corruption and Political Insurgency, 264.
} 
motivating factor for the war, despite the United States media's popularization of its role. $^{7}$

Prior to the war's end in 2002, the United Nations Mission in Sierra Leone (UNAMSIL) general purpose was to collaborate with the Sierra Leone government and other parties in implementing peace agreements between the Sierra Leone government and the RUF. UNAMSIL has been criticized for placing its policy of "national recovery and economic and social development" last on its proposed plan. ${ }^{8}$ Nevertheless, the UNAMSIL program has been a success story. But the world body would not have intervened toward the end of the conflict without the initiatives of the Nigerian-led Economic Community of West Africa (ECOWAS), a regional body that called for an intervention in the war through its ceasefire-monitoring group, ECOMOG. The move taken by ECOWAS governments would result in the restoration of constitutional legality and reinstatement of the government of the democratically elected President. ${ }^{9}$ ECOMOG faced similar issues in Sierra Leone in 1998 as it had in its attempts to end violence in Liberia in 1990 . However, the organization has been criticized by the Global Policy Forum for losing sight of its initial purpose and rather, becoming another faction of armed fighters in the war. ${ }^{10}$

\footnotetext{
${ }^{7}$ Lisa Denney, "Explaining War, Creating Peace: UK-Sponsored Reforms in Sierra Leone," Contemporary Review (Summer 2009): 154.

${ }^{8}$ Funmi Olonisakin, Peacekeeping in Sierra Leone: the Story of UNAMSIL (Boulder: Lynne Reinner Publishers: 2008), 40.

${ }^{9}$ Olonisakin, Peacekeeping in Sierra Leone, 45.

${ }^{10}$ Global Policy Forum, "Lessons of Sierra Leone Intervention," Security Council Issues (May 19, 1998): 2.
} 


\section{Statement of the Problem}

One of the most pressing issues facing post-conflict societies is the question of effective, successful reconstruction programs. Efficient implementations of programs that have a primary goal of tackling causes of war are needed in order for lasting peace to be achieved. The extant studies on the post-conflict reconstruction programs in Sierra Leone have so far failed to present the ways in which the policies and programs of reconstruction in the postwar context are addressing root causes of the war. For example, despite several studies of the post-conflict reconstruction programs, there is little or no attention paid to which strategies have been successful in establishing an infrastructure for sound democratic governance in the country in light of the causes of the war. The objective of this study is essentially threefold. In order to assess the relevance of the post-conflict reconstruction programs, this study will first present the background history of Sierra Leone, highlighting key historical features of the country's pre-colonial, colonial, and postcolonial eras. Providing an overview of the history will illuminate an understanding of how the country's colonial legacy played an important role in its postcolonial politics that essentially led up to the war. Then the study will reexamine the remote and proximate causes of the war-that is, those problems that had begun to accumulate since independence in 1961. Reexamining causation will give light to the various theories about what caused the war that have been put forth by scholars, and draw appropriate and accurate conclusions. Finally, the study will assess the ongoing postconflict reconstruction efforts aimed at restoring peace and stability to the country consistent with democratic governance. The background of the study will provide a solid 
context in which the main challenges the war has posed to the country's political, social, and economic future will be evaluated.

Since Sierra Leone was once a British colony, it would be illogical to ignore any possible nexus between colonial rule and the country's postcolonial condition of instability. Colonial rule in Sierra Leone sought to unite a country with a diversity of ethnic peoples through authoritarian rather than democratic methods. Colonial rule entrenched its autocratic political culture. ${ }^{11}$ Although some recent studies have alluded to this feature of causation, few, if any, have factored it into the ongoing reconstruction efforts aimed at creating a sustainable political peace and economic development within the framework of democratic governance. The findings of this study will be useful to policymakers and stakeholders involved in Sierra Leone because it will help them to refine their strategies and maximize available resources in order to achieve the goal of post-conflict reconstruction.

\section{Research Approach/Methodology}

The research design is to establish a relationship between causes of the war and the appropriateness of post-conflict reconstruction programs in order to predict the likelihood of political stability or the chances of a future war. The study holds the assumption that reconstruction programs need to address all of the root causes of war. Because one of the general outcomes of the study is to add to the discourse already produced, it looks at the existing literature on the history, causes, and programs in regards to the future of Sierra Leone. Sources of information for this will include the utilization of primary materials like archival materials, newspapers, government gazettes, and

\footnotetext{
${ }^{11}$ Bankole Thompson, The Constitutional History and Law of Sierra Leone (Lanham: University Press of America, Inc. 1997), 9.
} 
personal journals produced over the period of conflict and reconstruction, as well as oral accounts from participants and victims of the war. Other major sources of information include secondary materials in forms of textbooks, monographs, journal essays, and other similar materials. The approach consists of an analytical and comprehensive examination of the various aspects and dimensions of the conflict, challenges, and post-conflict measures.

It must, however, be conceded that at least one limitation to this study does exist, relating to the location of the area of study. Because the people-that is those who the said programs are targeting (i.e. youth, former combatants, and arguably the entire Sierra Leone populace) ultimately determines the success of a program, this study could benefit a great deal from interviews of people inside Sierra Leone, the ideal group to evaluate the effectiveness of their programs. Employing the personal interview method would allow the people of Sierra Leone to be active agents, and give them voices since they are often left out of the literature. These people are the ones directly affected by the ongoing programs and policies. Not having access to this population from Kentucky is a problem Hence, I attempted to address by documenting and examining the extensive literature on the various political, social, economic and related aspects of the war. In addition, interviews were conducted with Sierra Leonean officials and expatriates in the United States who were willing to answer questions about policies of reconstruction addressing causes of the conflict. These top officials and citizens were able to present information on the immediate postwar condition and some of the various programs on the ground (particularly UNAMSIL) and governmental policies. Because the interviews were historical in nature, and did not involve questions related to personal conducts in the war, 
the interviewees did not constitute human subjects of research and thus the research was exempt from the Institutional Review Board. Nonetheless, it should be noted that one flaw of the interview method in this case is the biases of interviewees, especially those who are not a part of the general civilian population and were possibly affected differently by the war. Some of these biases include the variety of perspectives brought by interviewees because of varied experiences. For example, individuals who were raped during the conflict, young children forced into fighting, or those that fled before the fighting began can all bring different accounts and insights.

Generally, information on the historical background of Sierra Leone was substantially drawn from the copious secondary sources in forms of books and journal articles. Because the historical timeline is important to understanding this study, the utilization of books and scholarly articles was inevitable. One of the foremost scholars who conducted research on Sierra Leone's political history, particularly in the postcolonial context, was Martin Kilson. He also conducted field research in Sierra Leone during that time period. Much of Kilson's pioneering research included primary sources, and this study particularly used his work Political Change in a West African State to interpret and analyze the historical precedents to the war. Other sources that are included in this section are David Keen's Conflict and Collusion in Sierra Leone and Bankole Thompson's The Constitutional History and Law of Sierra Leone, both of which look to Kilson's research as well.

The section on causes of conflict is reliant upon available primary sources, but more reliant on the use of secondary sources. A host of literature has been produced since the beginning of the war. Robert Kaplan in his Atlantic Monthly article "The 
Coming Anarchy," and Paul Collier and Anke Hoeffler in their paper "Greed and Grievance," were among the first to theorize as to what caused the civil war in Sierra Leone. The use of secondary sources in the sections on causation and post-conflict reconstruction is important in order to locate and interpret the war within the mainstream literature in a theoretical fashion. Reliance on these sources illustrates the wealth of research that has been conducted on the causes of conflict post-conflict reconstruction efforts. The void this study intends to fill, however, is to examine the existing literature and find trends that connect the reconstruction efforts to the causes of conflict.

After examining the causes of the civil war, and the challenges posed by the conflict, and the post-conflict reconstruction efforts and strategies, the study reviews the extant literature on the subject of post-conflict reconstruction programs in order to predict whether a future relapse to war is likely. This section relies largely upon primary sources such as official reports and policy brief. Others materials like Reports from Amnesty International, International Crisis Group Africa and the UN Secretary General, as well as official documents from the African Union and West Africa Early Warning and Response Network (WARN) were used because they provided firsthand accounts of some of the programs that were on the ground during the postwar period. The goal remains to fill a gap in the previous studies - that is to ascertain the relevance of the ongoing post-conflict efforts for a more lasting peace in Sierra Leone.

Structure of the Thesis

Chapter two is designed to be a general political history of Sierra Leone from the colonial era to the postcolonial era. It is divided into sections that explore the founding of the nation known today as Sierra Leone as a British post-abolitionist province of 
freedom. It highlights the unique colonial history of the country; the discovery of diamonds and the years leading up to decolonization; the immediate postcolonial era, its social, political, and economic disparities; the declaration of a one-party system and years of kleptocratic governance and misrule; and the emergence of the RUF.

Chapter three is a theoretical review of the prevalent literature of causes of war in Africa, with specific emphasis on Sierra Leone. It highlights the convergence of a very complex record of issues some scholars have variously identified as "greed and grievance," "inherent barbarism," corruption, mismanagement of natural resources, ethnic and political identity, structural violence and the social exclusion of basic needs resulting in marginalization, and the contagion of political conflict.

Chapter four also provides a theoretical review of the available literature and concepts on what constitutes the discourse and practice of post-conflict reconstruction. It emphasizes the necessity of development practitioners and policymakers, specifically in the postwar context, to focus on the causes of war if sustainable peace is to be attained.

Chapter five examines several of the ongoing post-conflict reconstruction programs in Sierra Leone. By way of post-conflict reconstruction, several organizations and peacekeeping projects were either established or sent to Sierra Leone to address the problems caused by the civil war and alleviate the resulting hardships. Two of the more high profile organizations include the United Nations Mission in Sierra Leone (UNAMSIL) and the Economic Community of West African States (ECOWAS). Humanitarian organizations such as Global Witness and International Crisis Group were at the forefront of relief efforts during and after the African conflict, with the United Nations as the leading organization. 
Chapter six, the final chapter of the study, is focused on the prospects for a peaceful, stable and democratic Sierra Leone. It is devoted to the analysis of specific programs of reconstruction and governmental policies, and examines how well they have addressed the causes of war. Specifically addressed are issues pertaining to corruption, youth unemployment, educational and health reform to indicate their position within the postwar development context. 


\section{Chapter II:}

\section{HISTORICAL BACKGROUND}

This chapter provides a concise historical survey of Sierra Leone and its political development from the pre-colonial period through the colonial and the postcolonial period and to the eve of the outbreak of civil war in 1991. Such history is important to appreciating fully the social dynamics of the country, particularly after it was granted independence from Great Britain in 1961. Oftentimes in the discussion surrounding identifying causes of war, what is initially explored are the problems that arise at that time. However, Sierra Leone's civil war was the result of a number of issues, which were a direct result of its colonial experience. This chapter argues that understanding the historical antecedents to the war provides a holistic view of the dynamics that led to the eruption of violence. Several themes emerge in this chapter that illustrates colonial factors that were prevalent after independence leading up to the war. They include:

- Ethnicity: this led to the rise of the indigenous elites through indirect rule as well as the creation of a new ethnic group, the krio elite,

- Centralization: sociopolitical and economic power was concentrated in the capital of Freetown during colonialism and after independence.

- Economy: a shift in the mode of economic development occurred, from a largely agricultural sector to diamonds upon their discovery. 
Ironically, each of these themes/events occurred subsequent to one another, and continued long after decolonization. The creation of ethnic identities that led to a hierarchy resulted in the centralization of power in Freetown, where the krio elites were located. Upon the discovery of diamonds, profits from these revenues were centralized among the elites, and exported to benefit outside businesses. Hence, David Keen rightly states that understanding Sierra Leone's war means understanding its history and the grievances it generated. $^{12}$

\section{The Founding of a "Free" Nation}

The country that is known today as Sierra Leone has interacted with European explorers since the $15^{\text {th }}$ century. The country was discovered and given its name by Portuguese traders in 1462, and the Dutch, French, and British followed suit in the business of trading African people. ${ }^{13}$ The colonial experience is believed to have begun, however, when in 1787 , Freetown, the small enclave that would later become the capital of Sierra Leone, was established as a settlement for freed slaves after a group of British philanthropists purchased the land near Bunce Island. ${ }^{14}$ The idea was to create a "province of freedom" for ex-slaves, particularly the "poor blacks" of Europe, along with white settlers. ${ }^{15}$ The Black Poor were a free, but marginalized group of Africans living in

\footnotetext{
${ }^{12}$ David Keen, Conflict and Collusion in Sierra Leone (New York: PALGRAVE, 2005), 2.

${ }^{13}$ Suzanne LeVert, Cultures of the World: Sierra Leone (New York: Marshall Cavendish Benchmark, 2007), 22; A. B. C. Sibthorpe, The History of Sierra Leone (London: Frank Cass and Company Limited), 7.

${ }^{14}$ Greg Campbell, Blood Diamonds: Tracing the Deadly Path of the World's Most Precious Stones (Westview Press, 2002), 28-31.

${ }^{15}$ Morten Boas, "Liberia and Sierra Leone: Dead Ringers? The Logic of Neopatrimonial Rule," Third World Quarterly (October 2001), 705.
} 
London, and the English philanthropists sought a solution for them. ${ }^{16}$ In May of 1787 a total of 411 settlers (including whites and blacks from Britain) arrived in the province of freedom. ${ }^{17}$ Hirsch contends that the establishment of Freetown as a British frontier marked the beginning of the colonial era in this region. ${ }^{18}$ Within a month of their arrival, however, the settlement was burned down by a Temne chief in retaliation for the earlier burning of one of his towns by a British warship. ${ }^{19}$ Thus, the initial settlement of this area was met with resistance to what was seen as an oppressive alien intrusion. This would be the story of Sierra Leone's development for years to come.

Despite this early resistance, the British were determined to establish a more formally organized colony. Following the founding of the colony by Granville Sharpe, a British philanthropist, control of the settlement was granted by Charter to the Court of Directors by the Sierra Leone Company in London. ${ }^{20}$ In 1791, the Sierra Leone Company garnered support from the British government to transport a group of blacks living in Nova Scotia, Canada. It was not until the arrival of the additional 1200 free blacks of Nova Scotia along with five hundred more from Jamaica in 1792 that Freetown was formally settled, and given its name. ${ }^{21}$ Until 1808, the settlement was characterized by rebellion, war and financial disasters. In order to bring about political stability, the

${ }^{16}$ Boas, "The Logic of Neopatrimonial Rule," 705.

${ }^{17}$ John Peterson, Province of Freedom: A History of Sierra Leone, 1787-1870 (Evanston: Northwestern University Press 1969), 7.

18 John Hirsch, Sierra Leone: Diamonds and the Struggle for Democracy (Boulder: Lynne Reinner Publishers, Inc., 2001), 23.

${ }^{19}$ Boas, "The Logic of Neopatrimonial Rule," 705.

${ }^{20}$ Bankole Thompson, The Constitutional History and Law of Sierra Leone (Lanham: University Press of America, Inc. 1997), 1.

${ }^{21}$ Boas, "The Logic of Neopatrimonial Rule," 705-706; Campbell, Blood Diamonds, 29. 
British government took over responsibility for the settlement in 1808 , and it was declared a crown colony in that same year.

Between 1808 and 1864, the original group of black settlers merged with a large number of Africans rescued from slave ships, reaching a number of roughly $70,000 .^{22}$ The Freetown settlers became known as the krio ethnic group, who modeled their governance after the colonial administration. This resulted in a cultural product that was more Afro-European than any other groups in that region. As a result, the Anglicized krio

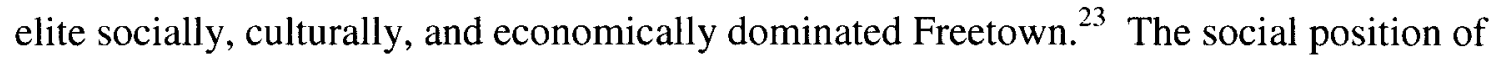
the krio remained largely unchallenged until the British government declared a Protectorate over the entire country in $1896 .^{24}$

While the krio dominated Freetown, the provinces were comprised of a diverse group of societies and political entities. Barrows describes this as a center-periphery dynamic. $^{25}$ Freetown, as Sierra Leone's urban metropolis and home to the country's most elite group was the center; whereas the rural area where groups such as the Mende, Temne, Vai and so forth inhabited with lesser political pull than the center were the periphery. ${ }^{26}$ However, the rural groups were not to be left out of colonial business for long, especially when the Protectorate was established.

\footnotetext{
${ }^{22}$ Boas, "The Logic of Neopatrimonial Rule," 705; Hirsch, Diamonds and the Struggle for Democracy, 23.

${ }^{23}$ Boas, "The Logic of Neopatrimonial Rule," 705; Hirsch, Diamonds and the Struggle for Democracy, 23; Pham, The Global Dimensions of an African Civil Conflict, 179.

${ }^{24}$ Boas, "The Logic of Neopatrimonial Rule," 706; Campbell, Blood Diamonds, 30-31

${ }^{25}$ Walter Barrows, Grassroots Politics in an African State: Integration and Development in Sierra Leone (New York: Africana Publishing Company, 1976), 1.

${ }^{26}$ Walter Barrows, Grassroots Politics in an African State, 1.
} 
The British implemented a form of governance called the indirect rule system, which was a method of colonial administration that used African chiefs as middlemen. ${ }^{27}$ Sierra Leone, then, is the product of an amalgamation of two separate colonial-era components, the Crown Colony of Freetown and the Protectorate of Sierra Leone, each of

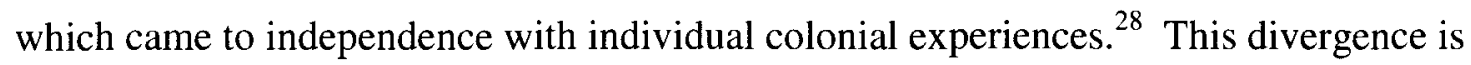
important in understanding Sierra Leone's political development, set in place by British colonial rule.

To add another dynamic, the Protectorate itself was a mixture of the indirect rule system through paramount chiefs and other traditional rulers. The chiefdom has been described as having two political functions. The first being the foundation of civil society, and the chief acting in the best interests of his people; and the second as the lowest component of the British administration. ${ }^{29}$ These factors could be mutually reinforcing or contradictory because the chief was met with the daunting task of maintaining a balance between traditional rule and colonial rule. This new role exercised through the chiefdoms would diminish the importance and dominance of the krio elite.

The British colonial administration was mainly concerned with obtaining and exploiting agricultural, material, and human resources of the area when they declared a Protectorate over the provinces. ${ }^{30}$ To some extent, the krio, who by default had become the educated elite among Freetown society, rendered parts of the rural lands

${ }^{27}$ Martin Kilson, Political Change in a West African State: A Study of the Modernization Process in Sierra Leone (Atheneum: Harvard University Press, 1969), 24.

${ }^{28}$ J. Peter Pham, The Global Dimensions of an African Civil Conflict from Child Soldiersk Adult Interests: The Global Dimensions of the Sierra Leone Tragedy (New York: Nova Sciences Publishers Inc, 2005), 179.

${ }^{29}$ Boas, "The Logic of Neopatrimonial Rule," 706; John R. Cartwright, Political Leadership in Sierra Leone (Buffalo: University of Toronto Press, 1978), 35.

${ }^{30}$ Kilson, Political Change, 14. 
commercially exploitable as well. ${ }^{31}$ Boas argues that this aspect of Sierra Leone's colonial history fostered a rivalry between two groups, the krio versus local chiefs. The end result of all these factors was Sierra Leone not being a united nation when independence was granted in 1961. It was "handicapped by its lack of national identity," and patron-client relations that were characteristic of the state in the country's postcolonial era were firmly set in place. $^{32}$

In addition to the ethnic social chasms that developed during Sierra Leone's colonial era, British rule created a pattern of economic development based on the extraction of unprocessed raw materials such as agricultural products, iron ore and diamonds. Raw materials were channeled out and manufactured goods were imported, resulting in a lack of industrial development and limited government stimulation for the rural economy. ${ }^{33}$

\section{The Discovery of Diamonds and Decolonization}

The discovery of diamonds in 1930 did not bring about much development for Sierra Leone because its profits were not used as a direct mode of economic development for the country. The country did, however, rely on the resource for its economic base because people were soon leaving the agricultural sector that had dominated the economy for so long, for the diamond mines. Soon thereafter, the diamond trade had taken over. Prior to the discovery of the precious minerals, the country was dependent upon the agricultural sector as its chief source of export earnings. However, when diamonds came into the picture, the alluvial mineral overshadowed the agricultural economy, and by

\footnotetext{
${ }^{31}$ Kilson, Political Change, 14.

${ }^{32}$ Boas, "The Logic of Neopatrimonial Rule," 707; Pham, The Global Dimensions of an African Conflict, 180.

${ }^{33}$ Keen, Conflict and Collusion, 8.
} 
1960, provided sixty percent of the value of Sierra Leone's exports. ${ }^{34}$ As a result, diamonds played a major role both in the prosperity of the 1950 s and 1960 s, and in the devastation of the war in recent years. ${ }^{35}$ From the beginning, the government was unable or unwilling to control the wealth for the benefit of its citizens. ${ }^{36}$ Due to the unearthing of diamonds in Sierra Leone's Kono District under the umbrella of British colonial rule, the profits from extraction benefited outside parties. However, the major mining deposits were located in the country's rural lands, bringing about questions as to who owned the region. The British used the Protectorate years earlier to their advantage. In 1935, the British-owned Sierra Leone Selection Trust (SLST), a De Beers subsidiary, was granted a ninety-nine year monopoly over diamond mining in the country. ${ }^{37}$ This resulted in the privatization of the public sector (i.e. natural resources), but not without the imposition of other external actors. For example, with the initial discovery of diamonds came Lebanese traders and businessmen who set up shop in the Kono District where the diamond mines were located. ${ }^{38}$ These factors were seen as contributing to the "business of conflict" that the country's postcolonial era would experience. ${ }^{39}$

${ }^{34}$ John R. Cartwright, Political Leadership in Sierra Leone (Buffalo: University of Chicago), 34.

${ }^{35}$ William Reno, "Political Networks in a Failing State: the Roots and Future of Violent Conflict in Sierra Leone" International Politics and Society 2 (2003): 48.

${ }^{36}$ Campbell, Blood Diamonds, 2.

${ }^{37}$ Rasna Warah, "Illicit Diamonds: Africa's Curse" (November 2004), 20; Hirsch, Diamonds and the Struggle for Democracy, 27;

${ }^{38}$ Warah, "Illicit Diamonds," 21.

${ }^{39}$ Tom Nevin, "The Business of Conflict, The Conflict of Business," African Business (July 2005): 21. 
This notion of "striking it rich" in the diamond mines was not only shared by external actors, but the people of Sierra Leone as well. ${ }^{40}$ As mentioned, the diamond mines drew a lot of workers away from the agricultural sector, which used to be the mainstay of Sierra Leone's economy. From the 1930s onwards, the "scramble" for diamonds foreshadowed any plans for a diversified economic development as revenues from diamonds sales represented an important component of Sierra Leone's economy. Arguably, the "conflict" element of diamonds began here because the country as an entity did not benefit much; rather, individuals and groups in and out of the country reaped greater profits. Despite Sierra Leone being home to one of West Africa's most valuable diamond deposits (that would over the next few decades produce roughly 50 million carats of diamonds), the country rarely reaped much benefit from its exports. ${ }^{41}$ The development that the country initially saw during the years leading up to independence would take a drastic turn after 1961. For that reason, one may assert that Sierra Leone's history exemplifies a sort of contradiction because prior to independence, the livelihood of the masses seemed to fare better than in the postcolonial era. The pattern of centralizing public commodities within the context of the state would be repeated in the immediate postcolonial era.

\section{Sociopolitical and Economic Disparities in the Postcolonial Era}

The characteristics of the sociopolitical and economic development did not significantly alter after independence in 1961. The generation of African elite that emerged during the colonial administration replaced the colonial oligarchy. The 1951

${ }^{40}$ J. A. Grant, "Diamonds, Foreign Aid, and the Uncertain Prospects for Post-conflict Reconstruction in Sierra Leone" Round Table (September 2005): 451.

${ }^{41}$ Campbell, Blood Diamonds, 9. 
Constitution provided a framework for decolonization, and after successful constitutional talks in London in 1960, Sir Milton Margai became Prime Minister. Thus, the shared political ideology of the African elite and the expatriate group, that is, the colonial administrators, was carried over into the postcolonial period. ${ }^{42}$ For instance, mining companies and industries continued to have poor linkages with the rest of the economy. Another element of continuity between colonial and independent Sierra Leone was the predominantly undemocratic mode of governance. ${ }^{43}$ The political continuities of centralization were also apparent as the undemocratic colonial system was followed by almost two decades of what was effectively a one-party state from 1973 to the military coup in $1992 .{ }^{44}$ The extractive economy and corrupt and autocratic political system appeared to be mutually reinforcing. In effect, the central government, both before and after independence, lacked the resources to fund a disciplined bureaucracy. Sierra Leone's history from independence in 1961 to the outbreak of violence resulting in the civil war in 1991 in essence foreshadowed the path of violence that would eventually engulf the country.

The postcolonial politics of Sierra Leone added another dynamic to the country's social milieu. The emergence of political parties among the krio ethnic group and "creolized" elite (chiefs) dominated the dimension of political parties. ${ }^{45}$ It has been argued that ethnicity played a role in political party affiliation as well as the election of

\footnotetext{
${ }^{42}$ Kilson, Political Change, 176.

${ }^{43}$ Keen, Conflict and Collusion, 8-9.

${ }^{44}$ Ibrahim Abdullah, "Bush Path to Destruction: The Origin and Character of the Revolutionary United Front/Sierra Leone," The Journal of Modern African Studies (June 1998): 206; Keen, Conflict and Collusion, 9; Olonisakin, Peacekeeping in Sierra Leone, 11; Riley, "Liberia and Sierra Leone," 12; Thompson, Constitutional History and Law of Sierra Leone, 145-175.

${ }^{45}$ Boas, "The Logic of Neopatrimonial Rule," 707.
} 
cabinet members into certain administrations. ${ }^{46}$ Following independence when Sir Milton Margai became the country's first Prime Minister, he represented the Sierra Leone People's Party (SLPP). The SLPP, founded in 1951, was the first legitimate political party in Sierra Leone, and primarily drew its membership from one of the two dominant ethnic groups in Sierra Leone, the Mende. ${ }^{47}$ The SLPP claimed to be a national party that transcended regional and linguistic distinctions, and included some Krio as well as Temne among its rank and file. ${ }^{48}$ After suffering months of illness, Margai died while in office in 1964, and was succeeded by his brother Albert. The new leader continued the old practice of allotting political positions to his ethnic Mende people.

Meanwhile, the All People's Congress (APC), founded in 1960, drew more of its supporters from the Temne ethnic group. The APC was a movement that appealed to a wide range of dissidents, including young people who felt that they had been marginalized by the government. The marginalization of youth that resulted in political mobilization was a feat that would be repeated in the rebel war, for the RUF was largely comprised of youth, both active and forced participants. The general consensus among APC supporters was that they had received the "short end of the stick" in regards to distribution and exchange of political and economic benefits. ${ }^{49}$ The APC won the elections in 1967 with Siaka Stevens as the head. Stevens was able to secure power because, prior to independence, the SLPP (with which he was originally affiliated) sought to decentralize the power the Krio elite had in governance for well over a century.

46 Jimmy D. Kandeh, "Politicization of Ethnic Identities in Sierra Leone," African Studies Review (April 1992), 81.

${ }^{47}$ Boas, "The Logic of Neopatrimonial Rule," 707; Pham, The Global Dimensions of an African Conflict, 183.

${ }^{48}$ Boas, "The Logic of Neopatrimonial Rule," 707.

${ }^{49}$ Boas, "The Logic of Neopatrimonial Rule," 707. 
However, as mentioned, the SLPP chose to accommodate those primarily of the Mende ethnic group. As a result, Stevens and others formed the APC, a party that was to be inclusive of all ethnic groups.

Kleptocratic Governance, Misrule, and a War Brewing in the Provinces

Siaka Stevens at times referred to himself and the APC Party as socialist, following a common ideology held by some African nationalists in the context of decolonization and the immediate postcolonial era. However, this populist agenda that the APC and Stevens purported soon proved to be a front for dishonest political reasons, and was not realized. Stevens' declaration as 'president for life' in Sierra Leone resulted in a centralized state and the eventual declaration of a one-party state in 1978 by the APC. ${ }^{50}$ The APC created a political atmosphere in which free and fair elections were no longer possible. This form of political control entrenched an economy that was heavily dependent on mineral resources, and as a result, the wealth that the government and elites accumulated would come from the diamond industry. ${ }^{51}$ Additionally, nepotism, the practice of favoring one's relations in socioeconomic and political appointments was a key problem in that patrimonial systems guaranteed positions of power would be given to those with connections to power rather than merit. ${ }^{52}$ Stevens was able to dominate Sierra Leone's politics through a combination of bribery and intimidation. ${ }^{53}$ Under the APC's reign, affluence was commonly attained through corrupt measures. Stevens' political

${ }^{50}$ Dumbuya, Reinventing the Colonial State, 11.

${ }^{51}$ Olonisakin, Peacekeeping in Sierra Leone, 11.

52 Denney, "Explaining War," 157.

${ }^{53}$ Hirsch, Diamonds and the Struggle for Democracy, 28. 
system was based largely on extending patronage to a relatively small group of "insiders" while intimidating "outsiders" who expressed their dissatisfaction. ${ }^{54}$

Similarly, in the provinces traditional chiefs kept in place a strict hierarchy based on social class through arbitrary systems. ${ }^{55}$ Thompson has written, "It was against the background of a colonial society used to autocracy in government, that the rulers of the new Commonwealth countries were brought up and learned the art of politics. The truth is that although they grew to dislike colonial authoritarianism, the emergent African elite inherited its legal and administrative superstructure at independence." 56

As the mismanagement of state funds became a key feature of governance following independence, the declaration of a one-party state in 1978 was a license for corruption on many levels. Prior to that, in 1971, the diamond company Sierra Leone Selection Trust (SLST) lost 51 percent of its shares to a government takeover. ${ }^{57}$ This move is said to have paved the way for increased national control of diamond revenues. Increase in government revenues failed to generate a corresponding improvement on the lives of average citizens as the majority of the profits found their way into private hands (i.e. Stevens and his Lebanese associates). ${ }^{58}$ Davies argues that while macroeconomic management is essential to the promotion of economic development, the successive Sierra Leonean governments exercised macroeconomic mismanagement, a key feature of the patrimonial system of governance blamed for the war. ${ }^{59}$

\footnotetext{
${ }^{54}$ Abdullah, "Bush Path to Destruction," 206-211; Keen, Conflict and Collusion, 16.

${ }^{55}$ Denney, "Explaining War," 157.

${ }^{56}$ Thompson, Constitutional History and Law of Sierra Leone, 9.

${ }^{57}$ Keen, Conflict and Collusion, 21.

${ }^{58}$ Keen, Conflict and Collusion, 21.

${ }^{59}$ Davies, "Sierra Leone's Development Challenges," 2.
} 
More evidence of the mismanagement of Sierra Leone's finances surfaced in 1980, during the country's preparation for the Organization for African Unity (OAU) conference. The entire year's budget was spent on the conference that was hosted in Sierra Leone. ${ }^{60}$ This move turned out to be an enormous and enduring burden on the country's finances. Denney states that the violence that ensued in the years to come was the result of issues related to political, social, and economic issues of equality, governance and security. ${ }^{61}$ Stevens' personal control of revenues destroyed state agencies as channels for patronage and made access to Stevens and not the state-the primary avenue to enrichment. ${ }^{62}$ The collapse of state services accelerated inflation and resulted in mass impoverishment, thus reinforcing the centrality of Stevens' official clandestine economy. ${ }^{63}$ During Stevens' one-party rule, as Thompson observed, the oneparty Constitution had become a legitimizing device for the introduction of autocratic and monolithic system of government dominated by the use of public emergency powers and measures as a technique of statecraft. ${ }^{64}$

Students at Sierra Leone's Fourah-Bay College, West Africa's first University modeled after western-styled universities, demonstrated against the Stevens' government in January 1977, insisting that it was an attempt to make the administration become aware of the views and needs of the people. ${ }^{65}$ The significance of the student political participation in Sierra Leone was that student protests were more pro-people rather than

\footnotetext{
${ }^{60}$ Keen, Conflict and Collusion, 25.

${ }^{61}$ Denney, "Explaining War," 157.

${ }^{62}$ Reno, "Political Networks in a Failing State," 56.

${ }^{63}$ Reno, "Political Networks in a Failing State," 56.

${ }^{64}$ Thompson, Constitutional History and Law of Sierra Leone, 174-175.

${ }^{65}$ Samuel Hinton, University Student Protests and Political Change in Sierra Leone (Lewiston: Edwin Mellen Press, Ltd. 2002), 59.
} 
anti-government. ${ }^{66}$ When the demands of the students that the president conduct fresh general elections and appoint a new cabinet were met, it was a victory for a somewhat muted public opinion vocalized by student political action. ${ }^{67}$

Student protests in Sierra Leone, particularly in 1977, were apparently successful because the participants believed that their actions would force the government to heed to the views and needs of ordinary people. Such actions could be construed to mean that students were active agents in the process of the "modernization" of their country by demanding that the government be proactive in responding to the needs of the people. Student participation in political activity was not considered a failure because of their efforts and minor successes. However, the greed of the regime they were up against proved a greater motivation for governmental officials.

When Stevens stepped down from the role of President in 1985, he made sure that the politics of his dictatorship would extend beyond the end of his tenure with his handpicked successor, Joseph Momoh. Momoh was chosen as a way for Stevens to protect his legacy and not hold him accountable for his malpractices and those of his business partners. ${ }^{68}$ Momoh was widely viewed by the masses as being more incompetent than Stevens. He proposed a political philosophy of "Constructive Nationalism" that claimed it would put the needs and interests of the nation above that of individuals, groups, or factions. ${ }^{69}$ Momoh was unable to resolve the issues that were at hand between a nation that had been aid-dependent, and the shadow state built on the

\footnotetext{
${ }^{66}$ Hinton, University Student Protests, 59.

${ }^{67}$ Hinton, University Student Protests, 59.

${ }^{68}$ Boas, "The Logic of Neopatrimonial Rule," 708; Pham, The Global Dimensions of an African Conflict, 181; Reno, "Political Networks in a Failing State," 56.

${ }^{69}$ Boas, "The Logic of Neopatrimonial Rule," 708.
} 
clandestine economy. ${ }^{70}$ In retrospect, Momoh's reign could be remembered as the period of Sierra Leone's complete economic collapse. The lack of formal control of the government along with the pressure from the international community to reduce the scope and strength of the state were precursors for what was brewing in the country's provinces.

The exercise of political power that was often intimately allied with violence or the threat of violence was characteristic of Stevens' regime and left a lasting legacy. It proved to be endemic to the country's social, political, and economic structure. The corruption, misrule, authoritarian tendencies, and just plain incompetence of the successive presidential administrations of Stevens and his protégé, Joseph Momoh, produced a vicious cycle that drew Sierra Leone inexorably into an abyss. ${ }^{71}$

Consequently, the connection between violence and political power found popular expressions in civil disobedience, rebel movements and a full-blown war.

\section{The Emergence of the Revolutionary United Front (RUF)}

When the RUF eventually made its way from Liberia into Bomaru in the Kailahun District of Sierra Leone in 1991, Foday Sankoh, leader of the group, announced to the world what the group was all about. ${ }^{72}$ Sankoh, a former army corporal and cameraman, had been a student leader in the 1970s and widespread critic of corruption. This was the beginning of his political career, as he witnessed the plundering of diamonds and other mineral wealth by Sierra Leone's political and military elite. As a

\footnotetext{
${ }^{70}$ Boas, "The Logic of Neopatrimonial Rule," 709; Reno, "Political Networks in a Failing State," 57.

${ }^{71}$ Nicolas Cook, Sierra Leone: Transition to Peace, ed. Brett Sillinger (New York: Nova Science Publishers, 2003), 17; Pham, Child Soldiers, Adult Interests, 77.

${ }^{72}$ Abdullah, "Bush Path to Destruction," 221.
} 
result, Sankoh held anti-government views and became increasingly radicalized. After losing his job as a cameraman and a brief imprisonment, Sankoh joined a group of Sierra Leonean dissidents in Libya, where they were under the tutelage of Col. Muammar AlGaddafi, who was sponsoring "revolutionary" movements. The movement would take on a nature of contagion when he later went to Liberia where he joined forces with another "revolutionary" leader, Charles Taylor, who would later become President of that country after its own bloody civil war. Sankoh eventually returned to Sierra Leone and was one of the founders of the RUF. The movement was initially fueled by violent rhetoric against the endemic corruption of the APC regime. They called for a "national democratic revolution," and put forth that it was their right and duty to change the political system that they were under in order for "national salvation and liberation" to be achieved. ${ }^{73}$ They stated that political and economic powers are inalienable rights of all people, and called for the building of social structures created by and for the people, which could be accomplished by revamping the educational system. ${ }^{74}$ The movement that had initially aimed to bring an end to corruption soon lost sight of its initial goals as deprived young men sought to make their own fortunes.

With its official genesis in the provinces, the conflict quickly expanded, and eventually encompassed all parts of the country. The conflict led to major political instability, resulting in two coups-in 1992 and 1997-and saw a serious deterioration of discipline within the Sierra Leone Army (SLA). ${ }^{75}$ Rural alienation was apparent because

\footnotetext{
${ }^{73}$ Basic Document of the Revolutionary United Front of Sierra Leone, "The Second Liberation of Africa," 1989.

${ }^{74}$ RUF/SL, "The Second Liberation of Africa, 1989.

${ }^{75}$ John Bellows and Edward Miguel, "War and Institutions: New Evidence from Sierra Leone" (April 2006), 394.
} 
civilians sought protection from state security sectors such as the police and military. However, according to most reports, elements of the SLA were colluding with the rebels throughout the war evidenced by the few battles between the two groups, as well as a faction of the SLA briefly entering into a formal political alliance with the rebels after the 1997 coup. $^{76}$ Therefore, people were rendered unprotected because the army soon took up arms as another faction. The term "sobel" resulted from this alliance because they were viewed as being soldiers by day and rebels by night. The "sobel" formed the AFRC with Johnny Paul Koroma as its leader, who would succeed in the 1997 coup that ousted newly elected Ahmed Tejan Kabbah. ${ }^{77}$ Nonetheless, there was still this question as to what caused this "sudden" outbreak of war in a country that after independence was not viewed as having such a grim future. ${ }^{78}$ The RUF's agenda was still unclear despite the circulation of The Basic Document, their manifesto. The "revolutionary" declaration did not coincide with their systematic attack on civilians. What was evident, however, was decades of inept governance that resulted in a neopatrimonial rule, the more recent being the corruption of the Momoh regime. These themes of corruption, contagion of conflict, and hinterland alienation would find their way into what caused the conflict.

The goal of this chapter was to provide an historical overview of Sierra Leone, emphasizing its immediate postcolonial condition to illustrate how the environment was fertile ground for protracted violence to occur. It argued that historical antecedents that led up to the war were a result of the colonial experience, and thus, need to be thoroughly

\footnotetext{
${ }^{76}$ Bellows and Miguel, "War and Local Institutions," 4; Olonisakin, Peacekeeping in Sierra Leone, 15; Riley, "Liberia and Sierra Leone," 15.

77 United Nations, "Second Progress Report of the Secretary General on the United Nations Observer Mission in Sierra Leone," October 18 1998, 8.

${ }^{78}$ Keen, Conflict and Collusion, 9.
} 
examined when considering the war's causation as well as the implementation of effective reconstruction programs. This chapter has demonstrated that prior to the outbreak of violence as led by the RUF, a war had been brewing long before the events of March 1991. Next, this study will critically attempt to locate the causes of the Sierra Leone civil conflict in a wider context of causes of civil wars in Africa along the lines of the historical narrative presented here.

The following chapters will illustrate that the reasons for the protracted civil war tearing Sierra Leone apart all point back to a legacy of British colonialism and the struggle by the ruling cliques to rob the country's wealth. Many of the internal problems that led to the civil war resulted from the way in which the country was established as a British base. The anti-colonial struggles that were common throughout much of Africa during the 1950s forced Britain to hand power over, but to a group of powerful elites that would plunder the country of its resources. These successive postcolonial regimes, specifically Siaka Stevens and Joseph Momoh's, would establish an environment of social exclusion and denial of basic needs to the populace. The RUF formed for a number of reasons, one of which being a reaction to the corrupt regimes. 
Chapter III:

\section{THEORIES ON THE CAUSES OF CIVIL WAR}

Civil wars and civil strife are but reactions to the pervasive lack of democracy, the denial of human rights, the complete disregard of the sovereignty of the people, the lack of empowerment and accountability and, generally bad governance. ${ }^{79}$ - Adebajo Adedeji.

There are varying theories as to the origin of the Sierra Leone conflict, which commenced in 1991 when the RUF launched an attack on the country that lasted until 2002. A decade of violence at the hands of various actors including, but not limited to the RUF rebel group, to the Sierra Leone Army (SLA), and Civil Defense Forces (CDF) incited a myriad of explanations of the origin of the war which resulted in the deaths of roughly 50,000 people, displacement of over one million, and amputation, rape, and assault on thousands. ${ }^{80}$

The purpose of this chapter is to explore the extant literature on the theories of causation, illustrate the plausibility of these theories, and critically examine how effectively they considered the socio-historical environment of Sierra Leone in order to substantiate their assertions. Understanding fully the causes of civil war in specific countries is significant for policymakers to address issues of postwar reconstruction in its

${ }^{79}$ Quoted from, Adebajo Adedeji, UN Economic Commission for Africa, quoted in Adekeye Adebajo, Building Peace in West Africa: Liberia, Sierra Leone, and GuineaBissau (Boulder, CO: Lynne Reinner Publishers, 2002), 15.

${ }^{80}$ Hala Jaber, "After the Horror, the Day of Justice," The Sunday Times (London: August 19, 2007); Human Rights Watch, "Sierra Leone: Getting Away With Murder, Mutilation, and Rape" (New York: Human Rights Watch) 1999; International Crisis Group, "Sierra Leone: Time for a New Military and Political Strategy" ICG (London: April 11, 2001), 2. 
entirety. The failure to examine fully the root causes of the conflict, or at least to provide an historical assessment of the country in question, often times results in the failure of local, regional, and international agencies and programs that have been established to aid postwar societies. Successes may be apparent in the rebuilding of basic and social infrastructures such as roads, homes, schools, governmental buildings and hospitals. However, if political instability finds its way into the same nation again, the previous issues were most likely not dealt with effectively. Therefore, especially in the case of Sierra Leone, it is imperative to understand the historical processes leading up to the war from a political, social, and economical perspective because of its importance in causing the war.

The theoretical background is explained also to situate the causes of civil war within a context that illustrates them as a continuum of colonialism. This framework includes arguments that affirm the need for reconstruction programs to address the causes of the civil war with an emphasis on strategies and techniques for achieving peace and prevention of conflict rather than providing ad hoc solutions.

Scholars have approached the question of what causes violent conflict in general, and Africa in particular from a variety of perspectives. These schools of thought have emerged in an attempt to understand the increasing and unending incidence of civil war in Africa. Although some were developed to explain specifically the African phenomenon, such as Paul Collier and Anke Hoeffler's greed and grievance theory, others were developed more generally, such as Mansoob Murshed's assertion that ethnicity plays a far larger role in civil wars because of its strong uniting force. Other conclusions blame the continent's deteriorating economic platform, control of the 
environment and mineral resources, ethnic feuds, the legacy of colonialism by creating a neo-colonial state, and postcolonial 'revolutionary' youth culture. This chapter explores in some detail the various theories and explanations as to the causes of war generally, and with specific reference to Africa, and Sierra Leone. The applicability of these claims to the Sierra Leone situation is relevant in order to understand fully all the causes of the war, hence, the need for their examination in that context.

Conclusions that have been drawn state that wars result mainly from territorial disputes (inclusive of natural resources), religion, and responses to oppression (i.e. unmet human needs). In regards to Sierra Leone, there seems to be a wider consensus that control of diamond resources was a significant cause of the war. It is a real irony that diamonds, a source of great wealth and prosperity, turned out to be a source of acute contentiousness among the people of Sierra Leone, resulting in national adversity and poverty. A mineral resource that would otherwise facilitate economic growth became a detriment, due primarily to the Sierra Leone Selection Trust's (SLST) monopoly over ninety percent of its revenues. Its privatization by successive governments contributed to its use as a weapon of the civil war. However, it is simplistic to contend that diamonds were the primary cause of the war. There were certainly other major dynamics that fostered an environment for violent conflict.

\section{Causes of the Sierra Leone Civil War}

Prior to the outbreak of violence, Sierra Leone, a nation that possesses significant mineral resources, but has a poorly developed economy, ${ }^{81}$ experienced a great deal of systemic government corruption with its successive regimes after independence, and thus,

\footnotetext{
${ }^{81}$ Nicolas Cook, Sierra Leone: Transition to Peace (Hauppauge: Nova Science Publishers, 2003), 17.
} 
established a character of political violence. Bellows and Miguel argue that the people of Sierra Leone responded to this systemic political violence with violence of their own, with an increased desire to assert their political rights rather than resignation, hence, the formation of rebel groups such as the RUF. ${ }^{82}$ Some sources have suggested that the country's abundant natural resources may have fuelled grievances there, particularly because people were aware that only a small group of political elites were reaping benefits of the natural wealth rather than the entire country. ${ }^{83}$ The main premise behind the separation of resources between governmental elites and the larger society is the deliberate deprivation of basic needs. Johan Galtung has alluded to such an occurrence as "structural violence." 84 It is violence embodied by a structure, and "characterized politically as repression and economically by exploitation. ${ }^{, 85}$

Arguably, the larger Sierra Leonean society endured such a fate. What is clear is that the causes of the conflict were complex, and the origins of instability extend back well beyond the decade leading up to the rebellion. ${ }^{86}$ Investigating all of the causal factors of war in Africa, specifically the Sierra Leone civil war, is vital in understanding ways to successfully implement reconstruction policies. However, in order to locate these causes, one must begin with examining the available literature that theorizes what causes war in Africa, specifically Sierra Leone.

${ }^{82}$ John Bellows and Edward Miguel, "War and Local Collective Action in Sierra Leone," Journal of Public Economics 93, (2009): 1147.

${ }^{83}$ David Keen, Conflict and Collusion in Sierra Leone (New York: PALGRAVE, 2005), 8.

${ }^{84}$ Johan Galtung, Peace by Peaceful Means: Peace and Conflict Development and Civilization (London: SAGE Publications, 1996), 197.

${ }^{85}$ Galtung, Peace by Peaceful Means, 93.

${ }^{86}$ Tony Binns and Roy Maconachie, "Going Home in Post-conflict Sierra Leone: Diamonds, agriculture and re-building rural livelihoods in the Eastern Province," Geography (2005), 67. 
The most popular among theories of the causation of African conflicts comes from Paul Collier and Anke Hoeffler, who have called their theory greed and grievance, which presents diamonds as the ultimate source of the fighting. However, Robert Kaplan was the first to address the Sierra Leone civil war by positing the intrinsic primitive nature of the African people as the source of blame. In his 1994 article from the Atlantic Monthly titled, "The Coming Anarchy," 87 Kaplan argues that underlying "primitivisms" of Sierra Leoneans (and African people in general) are what caused the outbreak of violence in the country. This "New Barbarianism" that is an inherent element of the culture was apparently brought to the forefront due to an environmental breakdown through overpopulation and resource shortage. ${ }^{88}$ In this essay, Kaplan establishes a "them" and "us" dichotomy but fails to address the role of the colonial power and that of the international community in creating or perpetuating the problems existing in Sierra Leone and other parts of Africa. Kaplan does not consider the historical problems of the colonial experience and how it continued to impact upon structures of governance in Sierra Leone past independence and the attendant impacts on the continent, which resulted in neocolonialism. Rather, he places emphasis exclusively on the so-called "savage nature" of the African person. Sierra Leone is a prime example of a nation that inherited and reinvented its colonial state in the postcolonial era. ${ }^{89}$ The author argues strenuously in this study that inquiry into the causes of conflict in African nations today that ignores the historical experiences of colonial rule is certainly flawed.

${ }^{87}$ Robert D. Kaplan, "The Coming Anarchy: How Scarcity, Crime, Overpopulation and Disease are Rapidly Destroying the Social Fabric of Our Planet," Atlantic Monthly 273, no. 2 (1994): 44-76.

${ }^{88}$ Kaplan, "Coming Anarchy," 46.

${ }^{89}$ Peter A. Dumbuya, Reinventing the Colonial State: Constitutionalism, One-Party Rule, and Civil War in Sierra Leone (New York: iUniverse, Inc, 2008), x. 
Paul Collier and Anke Hoeffler advanced another major theory on the causes of conflict in Africa by highlighting problems that were solely due to the economy and how they have contributed to civil wars in Africa. Their first paper, entitled, "On the Incidence of Civil War in Africa," applied an "econometric model of civil war" to analyze the incidence of civil war in Africa. The "Collier-Hoeffler model" of civil conflict, as it is commonly known, is in an attempt to evaluate the conclusions drawn by the Stockholm International Peace Research Institute (SIPRI), which concluded that Africa is the only region in the world where conflict is on the rising trend. ${ }^{90}$ Collier and Hoeffler found that on average, Africa had a rate of conflict that was very similar to that of other developing nations. The difference was, however, in its structure of risk, where Africa's economic characteristics generated an unusually high risk of conflict. Yet, the high risk factor is offset by social characteristics that generated an atypically low risk. Thus, the analysis suggested that the rising trend of conflict in Africa was not the result of deep-seated problems within the social fabric of the continent, similar to the conclusion drawn by Robert Kaplan. Rather, the authors concluded that it was due to the conditional effect of the economic circumstances. ${ }^{91}$

Their second paper, entitled "Greed and Grievance in Civil War," continues the economic approach to causation evident in the earlier work by focusing on the initiation of rebellion. ${ }^{92}$ This is explained by identifying the motive and opportunity for rebellion.

\footnotetext{
${ }^{90}$ Stockholm International Peace Research Institute (SIPRI), Yearbook of World Armaments and Disarmaments and International Security (Oxford: Oxford University Press, 1999), 20.

${ }^{91}$ Paul Collier and Anke Hoeffler, "On the Incidence of Civil War in Africa," Journal of Conflict Resolution (February 2002): 25.

${ }^{92}$ Paul Collier and Anke Hoeffler, "Greed and Grievance in Civil War," Oxford Economic Papers (2004): 564.
} 
Grievance, which includes high inequality, lack of political rights, and ethnic/religious divisions in society, are motivating factors for a rebellion; and the opportunity for rebellion to occur lies in the chance for financing rebellion. The RUF/SL was motivated by the abovementioned grievances, and further by the opportunity for diamonds to finance weapons for the war. Greed and grievance are explained as complementary forces in discussions surrounding violent conflict in Africa. Similarly, Paul Orogun in his article "Blood Diamonds and Africa's Armed Conflicts in the Post-Cold War Era" holds mineral resources responsible for Africa's civil wars, specifically in countries where diamond mining is a leading force. He asserts that some of Africa's most virulent conflicts have been characterized and catalyzed by the ruthless struggle for domination and control of vital economic resources such as diamonds. ${ }^{93}$

Along with these two popular theories is a set of arguments relating to local politics in Sierra Leone, rather than abstract ideas about the disintegration of the environment, essentialist culture or principal commodities. These views come predominantly from anthropologists and those from Sierra Leone who were involved in the war. ${ }^{94}$ They locate the key causes of the war in the systems of injustice and poor governance as operated/administered by the central government, as well as the traditional chieftaincy system in the provinces. Interviews conducted by Campbell during his time in Sierra Leone also lend support to theories on the inefficiency of the government, and

\footnotetext{
${ }^{93}$ Paul Orogun, "Blood Diamonds and Armed Conflicts in the Post-Cold War Era," World Affairs (Winter 2004): 152.

${ }^{94}$ Lisa Denney, "Explaining War, Creating Peace: UK-Sponsored Reforms in Sierra Leone," Contemporary Review (Summer 2009): 156.
} 
the difficulties that ordinary people had in working with natural resources in an honest fashion, thus mimicking the governmental protocol. ${ }^{95}$

Lisa Denney does not completely dismiss the greed and grievance based theory, conceding that mineral resources are a primary source of conflict. However, according to Denney in the case of Sierra Leone, mineral accumulation was used to fund the war after its genesis. ${ }^{96}$ The yearning for diamonds did not initially offset the civil war, but they facilitated its prolongation. The RUF forces would make use of diamonds as a financial backing for weapons, from the neighboring Liberian leader Charles Taylor. ${ }^{97}$ Denney reminds us that the war in Sierra Leone was fought for several years without major diamond income. $^{98}$ Diamonds were indeed the currency of choice with which the RUF used to purchase weapons from the neighboring Liberia (one of the many links between the wars in the two countries). ${ }^{99}$ The diamonds were essentially a means of continuing the rebels' struggle, but not the underlying purpose of it. ${ }^{100}$ On the strength of its findings, the Truth and Reconciliation Commission set out to manage the post-conflict resettlement and reconstruction programs further supports this assertion. ${ }^{101}$ Adebajo corroborates this view with the contention that the profits from diamonds were the primary factor in prolonging the war, but not the primary cause of conflict. ${ }^{102}$ Denney

\footnotetext{
${ }^{95}$ Campbell, Blood Diamonds, 43.

${ }^{96}$ Denney, "Explaining War," 156.

${ }^{97}$ Riley, "Liberia and Sierra Leone," 4.

98 Denney, "Explaining War", 156.

${ }^{99}$ Greg Campbell, Blood Diamonds: Tracing the Deadly Path of the World's Most Precious Stones (Westview Press, 2002), 39.

${ }^{100}$ James Rupert, “Diamond Hunters Fuel Africa's Brutal Wars," Washington Post (Washington: October 16, 1999).

${ }^{101}$ Truth and Reconciliation Commission for Sierra Leone, Final Report, 2004, 12.

${ }^{102}$ Adebajo, Building Peace in West Africa, 80.
} 
contends that Sierra Leone's civil war was a direct result of societal factors particularly the inept and corrupt governing body of the postcolonial era.

Stuart Hill and Donald Rothchild claim that war, specifically political conflict, presents itself in an area because certain ideologies that initiate war is contagious. These ideologies are often disseminated through media outlets such as newspapers and the radio. According to the authors, the process of contagion is due to the diffusion of group conflict from one country to another. Although they assert that conflict is rooted in the internal conditions of a particular country, people of different states share ideas, commerce, cultural traits, and conflict as well. ${ }^{103}$ The authors contend that the process of contagion is a specific process of social learning because watching groups in other societies organize and engage in political action, stimulates or heightens a sense of collective identity. ${ }^{104}$ In other words, a group that perceives itself as being a victim of a grievous treatment at the hands of its government or another group within the state may develop a clearer sense of its own political identity by observing the struggle in other countries. Thus, political conflict elsewhere can be instructive as to the means by which to pursue collective ends.

The Hill and Rotchild theory is further substantiated by Abdullah's analysis of the character of the RUF. Abdullah also examines how Sierra Leone became embroiled in a civil war from a variety of angles. One in particular is that outside forces contributed to a social learning of "revolution" that is an integral part of the process of contagion. The RUF's ideological leader, Foday Sankoh, along with other Sierra Leonean, Liberian and

\footnotetext{
${ }^{103}$ Stuart Hill and Donald Rothchild, "The Contagion of Political Conflict in Africa and the World," The Journal of Conflict Resolution (December 1986): 718.

${ }^{104}$ Hill and Rothchild, "Contagion," 719.
} 
Burkinabe mercenaries, received training from Col. Gaddafi of Libya on the makings of a revolution. ${ }^{105}$ Riley supports the theory of contagion by asserting that it was in Charles Taylor's strategic interest to assist the RUF in launching their "revolutionary" campaign in Sierra Leone. ${ }^{106}$ The neighboring failed state of Liberia was at that time in the midst of its own grim civil war. Since 1990, the Momoh regime had provided its only airbase to the West African peacekeeping force (ECOMOG) in Liberia. The organization intended to neutralize Liberia's top warlord at the time, Charles Taylor, who would become the country's future president. ${ }^{107}$ Sponsoring the RUF invasion was said to be Taylor's way of retaliating against Momoh.

Hill and Rothchild further suggest that ethnicity is also a deciding factor in how this process of contagion stretches across country limits. Because groups are usually formed around ethnic ties, ethnicity shapes the receptivity of domestically mobilized groups to outside conflict. This theme of ethnicity as related to violent conflict is shared among other researchers. Mansoob Murshed argues that many contemporary civil wars have an ethnic dimension, as ethnicity is a strong uniting force. ${ }^{108}$ Similarly, Blanton, Mason, and Athow contend that African countries that were under the British system of colonial administration are positively associated with ethnic conflict. ${ }^{109}$ It is to be noted, however, that Sierra Leone was, prior to the official arrival of British colonial rule in 1787, comprised of different ethnic groups such as the Mende and Temne. The creation of the

${ }^{105}$ Abdullah, "Bush Path to Destruction," 212; Cook, Sierra Leone: Transition to Peace, 20; Riley, "Liberia and Sierra Leone," 6.

${ }^{106}$ Riley, "Liberia and Sierra Leone," 7.

${ }^{107}$ Michael Chege, "Sierra Leone: the State that Came Back From the Dead," The Washington Quarterly 25, no. 3 (2002): 149.

${ }^{108}$ Murshed, "Conflict, Civil War, and Underdevelopment," 387.

${ }^{109}$ Blanton et al, "Colonial Style and Post-Colonial Ethnic Conflict in Africa," 483. 
Krio ethnic group as colonial elite, however, further fertilized the seeds for ethnic tensions. Most of Sierra Leone's 180-year colonial phase illustrated a fundamental political cleavage in Sierra Leone between the freed immigrants and anglicized Krio, and the multiethnic, multi-religious (Muslim, Christian, and indigenous) inhabitants of the country's provinces. In addition to this, the earlier part of the $20^{\text {th }}$ century in Sierra Leone also had a small business community made up of Lebanese and Indians. Although party political loyalties assume a loose ethnic divide between the predominant Temne of the north and the predominant Mende of the south, "Sierra Leone did not experience the ethnic fratricide that is often blamed for state collapse in Africa before or after independence." 110

Abdullah's main premise, however, is that the RUF was comprised of a "lumpenproletariat," a term originally coined in Marxist scholarship as a label for the poor masses. This "lumpenproletariat" is described as being unruly rural youth, former student radicals that resorted to criminal behavior, including violence, in order to achieve their goals. ${ }^{111}$ Although they received the short end of the stick, as it were, due to the inept one-party rule of Stevens' All People's Congress APC political party, they followed governmental example and resorted to violence to achieve a 'political' ends. Abdullah argues, nonetheless, that the RUF lacked revolutionary theory in their movement. In other words, they did not share any of the essential characteristics of ideology, organization and discipline, which marked revolutionary movements in Africa or

${ }^{110}$ Michael Chege, "Sierra Leone: the State that Came Back From the Dead," 148. 111 Abdullah, "Bush Path to Destruction," 206-207; Olonisakin, Peacekeeping in Sierra Leone, 12. 
elsewhere, except for the use of force to attain power. ${ }^{112}$ It is the greatest irony of the war that the very group that RUF attacked, the civilians, was the ones that they should have targeted for support if it was revolutionary change they were aiming to achieve.

The models so far analyzed are only a few of several explanations that attempt to define what causes violent conflict in general. Although most of them cannot be used as the sole determinant of what caused the civil war in Sierra Leone, they all have components that contributed in varying degrees to the war. These models were used primarily because theorists such as Kaplan, as well as Collier and Hoeffler were among the first and widely known when it came to identifying the causation of conflicts, with specific regard to Sierra Leone. The additional theories of ethnicity, corruption, and natural resources were included not only because they are popular topics as regards causation, but also to illustrate how these are the very same issues that arose during British colonial rule in Sierra Leone, as noted in the previous chapter.

In summation, it can be deduced that elements of ethnicity, greed, grievance, the contagion of political conflict, as well as corrupt and inept state governance among others, contributed to the outbreak of civil war in Sierra Leone. The historical evidence particularly stresses that the conflict originated, in part, from the growth of systemic government corruption in the decades after independence in 1961 , leading to a severe deterioration of state governing capacity. Keefer argues that "normal politics" is a determinant of civil war in that politicians do not follow up on the promises that are made to the citizens of the country. ${ }^{113}$ Adebajo ties these causes together by stating that

\footnotetext{
${ }^{112}$ Abdullah, "Bush Path to Destruction," 222.

${ }^{113}$ Philip Keefer, "Insurgency and Credible Commitment in Autocracies and Democracies," The World Bank Economic Review 22, no. 1 (2008): 1.
} 
"political misrule and economic decline of the postcolonial era created conditions for a rebel group that was backed by two sub-regional states", that is, Liberia and GuineaBissau. ${ }^{114}$ Again, the inference is irrefutable that the conflict was fuelled by contention over the control of mineral wealth, particularly diamonds, and other resources. The prolonging of conflict was illustrated by regional insecurity and external interference in the conflict—notably by the Liberian government, with which the RUF reportedly traded diamonds for arms and other assistance. Although the 1991 rebellion in the country was ignited by civil war in Liberia, it was essentially the underlying resentments inside the country that triggered the insurgency. ${ }^{115}$ All of these elements contributed to Sierra Leone's civil war. Based on the theories presented, one can conclude that while there are numerous reasons as regards the causes of conflicts, they occur primarily because of internal dissensions and dissatisfactions, with external influences as contributing factors.

${ }^{114}$ Adekeye Adebajo, Building Peace in West Africa: Liberia, Sierra Leone, and Guinea-Bissau (Boulder: Lynne Reinner Publishers, 2002), 103.

${ }^{115}$ Keen, Conflict and Collusion, 9. 


\section{CHAPTER IV:}

\section{THE CHALLENGES OF POSTWAR RECONSTRUCTION}

In the aftermath of violent conflict, there is one obvious priority, avoiding renewed violence. ${ }^{116}$

- Junne and Verkoren

This chapter highlights some of the present literature on the postwar reconstruction process, and the arguments as to what is needed for effective reconstruction in societies emerging from violent conflict. This includes a brief analysis of what is state failure and state formation in order to explore the apparent contradictions in Sierra Leone's categorization as a "failed state" (and its eventual complete collapse) up until its postwar state-building process. It begins by first defining the terms post-conflict (used synonymously with postwar in the context of this study), and peace because context is essential when drafting policies and programs of development. This is followed by what the major post-conflict reconstruction themes are (and should be) in the ongoing dialogue. The usage of specific terms coupled with the said goals of postconflict reconstruction all need to be taken into account when creating and assessing postwar programs of development.

Postwar Reconstruction: an Overview

${ }^{116}$ Quoted from, Gerd Junne and Willem Verkoren, Post Conflict Development: Meeting New Challenges (Boulder: Lynne Reinner Publishers, 2005), 12. 
The term post-conflict is defined as: conflict situations in which open warfare has come to an end. ${ }^{117}$ However, these situations can remain tense for years or decades and can engage in an effortless degenerative path, reverting back to large-scale violence. Some studies have shown that forty-four percent of all post-conflict situations are met with the resumption of war within the first 5 years ${ }^{118}$, whereas fifty percent of post-conflict countries revert back to war in the first decade of peace. ${ }^{119}$ Post-conflict (also postwar) is oftentimes used as a synonym for peace. However, more often than not, post-conflict societies have experienced a breakdown in the societal structure that makes the security sector vulnerable. If security forces (i.e. police and military) are weak, citizens remain defenseless if violence is to reoccur. Peace, on the other hand involves not just the end of war but the absence of significant residual violence, undivided sovereignty, and a minimum level of political openness. ${ }^{120}$ Peter Uvin discusses the debate on "positive peace" versus "negative peace," which states that peace is not simply when people or nations do not fight one another (or in Sierra Leone's case, cease to fight), but the existence of cooperation, trust and respect between them in present as well. ${ }^{121}$ In fact, transitioning from civil war to sustainable peace is a complex process. Similarly, some of the common assumptions underlying the concept and practice of development is that an external source, either regional or international, provides only monetary support for the country where aid is needed, also called the "host country", in addition to building or

\footnotetext{
117 Junne and Verkoren, Post Conflict Development, 1.

${ }^{118}$ World Bank Report, 2004, $8<<$ retrieved from Junne and Willem, 2005.

${ }^{119}$ Paul Collier et al, "Breaking the Conflict Trap: Civil War and Development Policy," (Washington, D.C.: World Bank), 7.

${ }^{120}$ Ibrahim Ahmed Elbadawi, "Post-conflict Transitions: An Overview," The World Bank Economic Review 22, no. 1 (2008): 2.

${ }^{121}$ Peter Uvin, Life After Violence: A People's Story of Burundi (New York: Zed Books, 2009), 43.
} 
rebuilding tangible infrastructures such as roads, hospitals, etc. However, development is beyond the minimalist assumption of referencing economic growth, but about improving the standard of living for all people in poor countries. ${ }^{122}$ In reality, economic development itself is no guarantee against violent conflict. Nevertheless, the lack of development can be a catalyst for the resumption of violence. ${ }^{123}$ Studies have shown that development is a precondition for security and economic development might reduce the occurrence of violent conflict. ${ }^{124}$

Violent conflicts at the end of the twentieth century have devastated many developing countries and impeded development efforts in which large amounts of human energy and money were invested. Primarily in the region referred to as Third World or Global South, many countries are actually worse off than they had been when they became independent. With every violent conflict, a social order loses part of its ability to handle future conflicts in a nonviolent and meaningful way. ${ }^{125}$ With that said, there is a necessity for international as well as local and regional organizations to understand the causes of conflict in order for lasting peace to be achieved. Junne and Verkoren assert, "Humanitarian organizations rush in but are neither interested in the causes of the conflict nor in long-term development." ${ }^{, 26}$ In actuality, for long-term sustainability of peace and growth to be achieved, post-conflict societies need to develop institutions for the delivery of public goods, which can only be fulfilled through leaders who are in a position to

\footnotetext{
122 Junne and Verkoren, Post Conflict Development, 3.

123 Junne and Verkoren, Post Conflict Development, 2.

${ }^{124}$ Rolf Schwarz, "Post-Conflict Peacebuilding: The Challenges of Security, Welfare, and Representation," Security Dialogue 36, no. 429 (2005): 437.

${ }^{125}$ Hugh Miall, Conflict Transformation: A Multi-Dimensional Task, in Berghof Handbook For Conflict Transformation (Berlin: Berghof Research Center for Constructive Conflict Management), 15.

${ }^{126}$ Junne and Verkoren, Post Conflict Development, 5.
} 
overcome political fragmentation. The formation of stable national coalitions beyond immediate ethnic or regional power bases will foster an atmosphere of national unity beyond political divides. ${ }^{127}$ Therefore, development efforts must take the conflicts unequivocally into account. More importantly, planners must speak to the causes of conflict in order to find ways to prevent them from reoccurring. Researchers have stated that development policies for conflict-torn societies have to differ in accordance with the causes of conflict. In other words, there must not be a "one-size-fits-all" approach when proposing policies of development in regards to causes of violence. Thus, the challenges of post-conflict development differ with the reasons for conflict in general.

To approach the discussion of post-conflict reconstruction holistically, Junne and Verkoren put forward what they term as "four clusters of causes" in order to assess what and how postwar programs of development should be implemented. These causes include the external or international impacts; the characteristics of the state of the country in question; characteristics of society; and individual orientations. ${ }^{128}$

The argument on external or international factor states that the root causes of conflict are found outside of the country in question as a result of the remnants of colonial rule. Consequently, groups are set up against one another by outsiders. This category additionally claims that these hostilities are the result of globalization, which exposes the whole societal structure to severe outside competition, subsequently aggravating the inner competition for resources. Marda Mustapha further supports this theory by holding that Sierra Leone's postwar society characterizes an environment that

${ }^{127}$ Elbadawi, "Post-conflict Transitions," 1.

${ }^{128}$ Junne and Verkoren, Post Conflict Development, 7. 
is emblematic of "structural violence," which is a consequence of not only the internal workings of the corrupt government but also the broader impacts of global capitalism. ${ }^{129}$ The next cause addressed involves the characteristics of the state. This involves the state being too strong or too weak. A weak state is not capable of protecting its citizens who may then turn to sub-national groups and thus, challenge the authority and legitimacy of the state. Contrastingly, a state can be repressive, giving rise to resistance. In the case of Sierra Leone, the state had begun a downward spiral trend since independence because of the oppressive manner of governance adopted by the political elites. Additionally, there is Ibrahim Abdullah's analysis that the Revolutionary United Front (RUF) of Sierra Leone was comprised of "lumpen" youth who had been aggrieved by the state and thus turned to sub-national grouping. Consequently, Sierra Leone's decline into war fits both of the aforementioned descriptions.

The third reason is the characteristics of society. This is indicative of economic inequalities that lead to class struggle, ethnic cleavages, excessive use of natural resources causing quandaries about inadequate means of living, or plentiful resources may lead to conflict. The final cause put forward by Junne and Verkoren is individual orientations. In other words, "people are divided among different political ideologies, different religions, or different languages (culture, images, and customs)" ${ }^{130}$

The fundamental task of post-conflict development is not just rebuilding or reconstructing. This may, in fact, lead to recreating the very structures that gave rise to the devastating conflicts, and thus create a vicious relapse to violence. The immediate

${ }^{129}$ Marda Mustapha, "Global Inequalities and Peace in Post-War Sierra Leone," Unpublished Paper, 1.

${ }^{130}$ Junne and Verkoren, Post Conflict Development, 7. 
aftermath of these conflicts can create a political window of opportunity in which all parties, and more importantly, the state and civil society, agree that basic structures of society have to be changed to avoid a recurrence of devastation. Therefore, reconstruction and peace-building can succeed only when all the different actors and networks are committed to and contribute in peace talks. Civil society groups are key in contributing greatly to the moral, economic, and humanitarian reconstruction efforts in the country. ${ }^{131}$

Adekeye also identifies the importance of post-conflict peace-building, and some tasks that are involved in this process. These include: 1) disarming and demobilizing warring factions; 2) conducting and observing elections; 3) repatriating and resettling refugees; 4) rehabilitating and reintegrating soldiers into local communities; 5) restructuring and reforming security forces, civil services, and judiciaries; 6) monitoring and investigating human rights abuses; and 7) overseeing transitional civilian authorities. $^{132}$ Similarly, in his book on the aftermath of the Burundian civil war, Peter Uvin mentions the post-conflict agenda according to the international community as implementing measures for achieving: security sector reform (SSR), demobilization, disarmament and reintegration (DDR), governance (creation of a democratic polity), development (economic growth), and justice/reconciliation. ${ }^{133}$ Both scholars take the view that political, social, and economic aspects of society should be taken into

\footnotetext{
${ }^{131}$ Ahmad A. Sikainga and Ousseina Alidou, Post-conflict Reconstruction in Africa, (Trenton: Africa World Press, 2006), 8.

132 Adebajo, Building Peace in West Africa, 19.

${ }^{133}$ Peter Uvin, Life after Violence: a People's Story of Burundi (New York: Zed Books, 2009), 43.
} 
consideration when looking at countries emerging from war, in an effort to address the root causes.

From 'State Failure' to Postwar State Building

According to Schwarz, "conflict, state collapse, state reformation, and peace-building" (also state building), share a symbiotic relationship. ${ }^{134}$ In the post-Cold War era, conflicts and wars have increasingly been accompanied by state failure and state collapse, thus the need for reconstruction that is specific to postwar contexts. Since the end of the "medieval order," what the world views today as the "modern state" has been a continuous work in progress. ${ }^{135}$ The modern state is often compared to, or riding on the coattails of the state referenced in eighteenth century literature. However, it is against this backdrop that current discourse on the "failed" or "collapsed" state must be understood. $^{136}$ The attention that has been allotted to state failure and state collapse is fascinating to some scholars, considering the disappearance of states is a rare occurrence. ${ }^{137}$ Nevertheless, this analysis is important to the study and beyond because Sierra Leone is one of those "few" cases in which state collapse was eminent, and the growing discussion of what constitutes a state, therefore, state failure. ${ }^{138}$

\footnotetext{
${ }^{134}$ Rolf Schwarz, "Post-Conflict Peacebuilding: the Challenges of Security, Welfare and Representation," Security Dialogue (December 2005): 430.

135 Jennifer Milliken and Keithe Krause, State Failure, State Collapse, and State Reconstruction: Concepts, Lessons, and Strategies, ed. Jennifer Milliken (Malden: Blackwell Publishing Ltd, 2003), 1.

${ }^{136}$ Milliken and Krause, State Failure, State Collapse, and State Reconstruction, 1. ${ }^{137}$ Schwarz, "Post-Conflict Peacebuilding," 430.

${ }^{138}$ This categorization of full-blown state collapse remains rare, but was seen in cases such as Liberia, Sierra Leone, Somalia, Congo/Zaire, and Albania. See Milliken and Krause, State Failure, State Collapse, and State Reconstruction, 2. Schwarz also argues that complete state collapse is a rare phenomenon that has received a lot of attention, in "Post-Conflict Peacebuilding," 430.
} 
Schwarz argues that functional state failure should be distinguished from state collapse. The former is defined as a deformation in which the state fails to provide its most basic functions to civil society, whereas the latter is where the complete order breaks down and a war of all against all emerges. ${ }^{139}$ This definition of state failure is similar to Johan Galtung's theory of the structural violence, which is the suppression of basic needs to society by the state. ${ }^{140}$

The term "failed state" has emerged with its own set of controversies. What is oftentimes overlooked is that most of what we know as Western society had undergone state formation for centuries, and violence, whether cross border or intra-state played an integral part of that process. With that said, the formation of Sierra Leone and other African nations into states, when described in Western terminology, should be placed within a context of the historical processes of state formation. Consequently, it can be argued that because much of Africa has been independent for roughly fifty years this process of state formation is not simply due to a "savage African" frame of reference, nor to endemic political, economic, and social issues. Because the current dispensation is based on technological advancement, Africa is seen as backwards when it can be argued that it is experiencing a process that shows very little difference from European states when they were forming in the pre-colonial era.

Sierra Leone was politically independent for roughly six years before the All People's Congress (APC) party came to power with Siaka Stevens as its head and

${ }^{139}$ Schwarz, "Post-Conflict Peacebuilding," 430.

${ }^{140}$ Johan Galtung, Peace by Peaceful Means: Peace and Conflict Development and Civilization (London: SAGE Publications, 1996), 93; John J. Hamre and Gordon R. Sullivan, "Toward Post-conflict Reconstruction," The Washington Quarterly (Autumn 2002): 85. 
centralized all aspects of the state. Stevens' practices of nepotism and corruption undercut the growth of the economy in a manner worse than it was around the immediate postcolonial era. ${ }^{141}$ As a result, the regime left no room for legitimacy and the country was barely a state when it began to indicate characteristics of state failure. As earlier elaborated upon, the formal political system was further undermined in the 1970 s and 1980s when Sierra Leone slipped into a one-party system of governance. Citizens were experiencing failure from the official states and exclusion from the informal state, which was comprised of patronage networks. ${ }^{142}$ An element of distrust was established among the civilian population in regards to the government. Nonetheless, the role the state plays in postwar reconstruction is one of importance because it is from there that national trust is to be built.

The Role of the State in Postwar Reconstruction

Junne and Verkoren assert, "The growing attention for the role of the state in development is also related to the increasingly pressing issues of post-conflict development, which is burdened with heavy political problems." ${ }^{143}$ Government officials are often met with the task of how to deal with the terror exacted by rebel insurgents upon their nations. Before the official end of Sierra Leone's eleven-year war, representatives from both the government and RUF met in Lome, Togo from May 25, 1999 to July 7 of that same year, to negotiate unity between the RUF and the government,

${ }^{141}$ Kieran Mitton, "Reconstructing Trust in Sierra Leone," The Round Table (August 2009), 463.

${ }^{142}$ Mitton, "Reconstructing Trust in Sierra Leone," 463.

${ }^{143}$ Junne and Verkoren, Post Conflict Development, 5. 
then headed by President Tejan Kabbah. ${ }^{144}$ During the negotiations, the RUF sought amnesty, ministerial positions in the transitional government for specific members from its faction, and the position of Vice-President for its leader, Foday Sankoh. What came to be known as the Lome Peace Accord granted the wishes of the RUF, with the exception of Sankoh's vice-presidential role. The United States took a behind the scenes role in granting amnesty to the RUF. ${ }^{145}$ Former U.S. Secretary of State Madeleine Albright met with RUF leaders Foday Sankoh and Johnny Paul Koroma, supporting the immunity that the Lome Accord would grant. ${ }^{146}$ This agreement later proved abortive because of the continuance of the war up to three years after it was concluded.

Scholars have approached the discussion of peace accords from several perspectives. One such response contends that the failure of peace accords has been largely due to impracticable assumptions about the person or group's involved motivation to play by the rules. ${ }^{147}$ Consequently, state leaders make "fatal" mistakes of granting political roles to individuals who have committed atrocities. ${ }^{148}$ Examples of this include Jonas Savimbi of Angola, Charles Taylor of Liberia, and Foday Sankoh and the RUF of Sierra Leone. These "fatal" mistakes can result in the rebuilding of pre-conflict institutions. The reconstruction of pre-conflict political structures may contribute to lengthening the conflict, or even resuming the violence, rather than solving it. This is an issue due in part to pre-conflict structures often contributing to the causes of the conflict

\footnotetext{
${ }^{144}$ Abiodun Alao and Comfort Ero, "Cut Short for Taking Short Cuts: The Lome Peace Agreement on Sierra Leone," Civil Wars (Autumn 2001): 120.

${ }^{145}$ Steven Mufson, "U.S. Backs Amnesty in Sierra Leone," Washington Post (Washington: October 18, 1999).

${ }^{146}$ Karl Vick, "Albright Meets With Sierra Leone Rebels," Washington Post (Washington: October 19, 1999).

147 Junne and Verkore, Post Conflict Development, 23-27.

${ }^{148}$ Junne and Verkoren, Post Conflict Development, 20-21.
} 
because some groups benefited over others, continuing an environment of social exclusion. In the case of Sierra Leone with the signing of the Lome Peace Accord, civilians who were subjected to violence by the RUF and the smaller actors in the war were at a disadvantage.

The achievement of independence of societies such as Sierra Leone was accompanied by significant changes in its political, economic and social structures. Sierra Leone's pre-conflict government was characterized by a concentration of power among political elites and the few that were part of the masses (patron-client relationship). In the pre-conflict society, governmental positions were based on a patronage network, and these positions were often given to a specific group of the population or people willing to do the biddings of their political predecessors.

Additionally, government expenditures were regionally concentrated. For success to be realized in the post-conflict society, access to government positions has to be open to all groups of people, and there should be more stability along the lines of regional infrastructure. Moreover, the need for governmental transparency should be among the foremost concerns addressed when discussing fostering better relationships between the state and society.

Baker and May address the issues of reconstruction in postwar Sierra Leone by examining youth alienation, state corruption, and national reconciliation. They examined which external aid programs addressed the underlying factors that predisposed Sierra Leone to internal conflict, and measured how effective they are in promoting a level of 
peace on which to rebuild social and economic life. ${ }^{149}$ This issue is of importance because one cannot simply rebuild the infrastructure and return to the pre-war condition, which was characterized by decades of injustice, corruption and authoritarianism. ${ }^{150}$ According to Baker and May, Sierra Leoneans have affirmed that the two primary causes of the war are bad governance and marginalization of youth. ${ }^{151}$ Political credibility is a necessity when promoting postwar reconstruction. Keefer has argued that when weakly credible leaders cannot persuade the majority of their citizens to believe their promises, they then enact policies that benefit the few groups that support them. ${ }^{152}$ This, in essence, promotes an atmosphere of exclusion and a violent cycle wherein the majority of the population is not provided with public goods, while the few are experiencing an overprovision and encourages insurgency. Ironically, good governance is highlighted as a fundamental prerequisite for building lasting peace in a country both before and after conflict has ended.

This chapter has sought to provide a nexus between the causes of war and the post-conflict reconstruction setting. The present literature on post-conflict reconstruction seeks to connect these postwar strategies and implementation with the original causes of war. Its main premise is that in order for countries that have emerged from war to not revert back to violence, effective measures have to be put in place by local, regional, and international actors that address firstly the causes of violence. The chapter has also examined the issues and process of peace building in war-torn societies. This was

${ }^{149}$ Bruce Baker and Roy May, "Reconstructing Sierra Leone," Commonwealth and Comparative Politics 42, no. 1 (2004): 35.

${ }^{150}$ Baker and May, "Reconstructing Sierra Leone," 36.

${ }^{151}$ Baker and May, "Reconstructing Sierra Leone," 38.

${ }^{152}$ Philip Keefer, "Insurgency and Credible Commitment in Autocracies and Democracies," The World Bank Economic Review (2008): 1. 
illustrated in the analysis of failed states and post-conflict state building, in particular ways in which a society develops the state institutions. 


\section{CHAPTER V:}

\section{POSTWAR SIERRA LEONE: INSTITUIONAL AND SOCIETAL REFORM}

This chapter analyzes a few of the post-conflict reconstruction programs in Sierra Leone in light of the major causes of the war with particular emphasis on the postwar era from 2002 onward. So far, the weight of available evidences have shown that the Sierra Leone civil war was precipitated by governance issues, the inability of the government to respond to the people's needs and expectations, especially in regards to the rural populations. This process of exclusion led to the marginalization of rural youthamongst whom aggravation and discontent festered. This fueled the incessant need for the country to be placed back into the hands of the people; however, the greed for Sierra Leone's alluvial diamonds and other wealth producing natural resources became a primary determinant for why the war continued for a decade.

Some of these programs and organizations were established prior to the war's official end. However, they are just as important as those that intervened in the postwar context. Such programs include those implemented by international interventionists like the United Nations Mission in Sierra Leone (UNAMSIL) and regional assistance such as the Economic Community of West African States Monitoring Group (ECOMOG). More local organizations such as Children's Learning Services (CLS) were created to address the issues of inadequate schooling and the question of what to do with former child combatants. Additional programs created by Great Britain that address national security because of its importance in the immediate postwar context are examined as well. 
While the civil war in Sierra Leone formally began with the Revolutionary United Front (RUF) invasion of the country on March 23, 1991, and officially ended with the United Nations (UN) declaration of the cessation of hostilities on January $18,2002,{ }^{153}$ the small West African nation did not immediately become a symbol of peace. On the contrary, Sierra Leone was considered a failed state and questions as to proper implementation of postwar recovery efforts were posed. The UN along with other local, regional, and international nongovernmental organizations (NGOs) was brought into Sierra Leone to establish programs that would address the country's failures. These included programs for disarmament, demobilization, and reintegration (DDR) efforts; rehabilitation of former combatants; educational and healthcare reform; state building through reinvigorating of old institutions and establishing new ones; and addressing issues of national security through restructuring of the military and police, among others. Even though the war officially ended eight years ago, the study has shown that arguments still abound as to what actually caused the conflict, and thus what measures are now needed to ensure peace and progress towards sustainable development.

There have been numerous efforts to improve Sierra Leone, from various local, regional, and international actors. Great Britain, its former colonial power, specifically has been in the lead among other international interventionist actors. ${ }^{154}$ At the same time, very little is documented about how well these processes of reconstruction have aligned with the root causes of the conflict. This study has sought to fill in that gap.

${ }^{153}$ J. Peter Pham, The Global Dimensions of the Sierra Leone Tragedy: Child Soldiers, Adult Interests (New York: Nova Sciences Publishers Inc, 2005), xix.

${ }^{154}$ Lisa Denney, "Explaining War, Creating Peace: UK-Sponsored Reforms in Sierra Leone," Contemporary Review (Summer 2009): 153. 


\section{Post-conflict Reconstruction in Sierra Leone}

Before and after the war ended on January 18, 2002, Sierra Leone received support from international donors to aid post-conflict reconstruction efforts. These international donors included but were not limited to, the World Bank, United Nations Mission in Sierra Leone (UNAMSIL), the European Commission, and the United Nations Development Program (UNDP). ${ }^{155}$ It is, however, important to mention the initial hesitancy of the World Bank in helping Sierra Leone near the end of its war. Dreher et. al. argue that membership on the United Nations Security Council (UNSC) influences the World Bank decisions on whether or not to intervene on behalf of a country as regards funding for security issues. ${ }^{156}$ As the study will later show, the UK's involvement in Sierra Leone was largely to reform the security sector and this was predicated on their position on the UNSC.

UNAMSIL has been described as a model peacekeeping mission, and at its peak in 2002 was the largest and most expensive UN mission on the ground in one of the smallest nations in Sub-Saharan Africa. ${ }^{157}$ Although British intervention is seen as a "success," regional actors, too, led in efforts to manage the conflicts in Sierra Leone, Liberia, and Guinea-Bissau. Adebajo contends that the regional approach is important in conflict management because of the interdependent nature of security issues. ${ }^{158}$ This was especially important in Sierra Leone's case due to the spillover effect from Liberia's

\footnotetext{
155 Denney, “Explaining War," 158.

${ }^{156}$ Axel Dreher et al, "Development Aid and International Politics: Does Membership on the UN Security Council Influence World Bank Decisions?" Journal of Development Economics (2008): 1.

157 'Funmi Olonisakin, Peacekeeping in Sierra Leone: the Story of UNAMSIL (Boulder: Lynne Rienner Publishers, Inc, 2008), 111.

${ }^{158}$ Adebajo, Building Peace in West Africa, 18-19.
} 
brewing civil war. Therefore, the intervention of international NGOs was necessary to complement the efforts of the local and regional organizations that were already on the ground.

Economic Community of West African States (ECOWAS)

Among the regional interventionists involved in attempting to establish peace in Sierra Leone was ECOWAS. ECOWAS is a regional group consisting of fifteen countries that was founded in 1975 . The countries that constitute the organization include Benin, Burkina Faso, Cape Verde, Cote d'Ivoire, Gambia, Ghana, Guinea, Guinea Bissau, Liberia, Mali, Niger, Nigeria, Senegal, Sierra Leone, and Togo. ${ }^{159}$ While their mission is the promotion of economic integration in areas pertaining to energy, agriculture, natural resources, etc., their mission in Sierra Leone with their monitoring group (ECOMOG) was to bring peace to a conflict that had spillover effects.

ECOWAS's intervention in Sierra Leone was to contain the crisis. The organization came in with a six-point peace plan to return Constitutional Governance to Sierra Leone. ${ }^{160}$ These goals included:

1. Cessation of hostilities

2. Disarmament, Demobilization, and Reintegration of combatants

3. Commencement of humanitarian assistance

4. Return of refugees and displaced persons

5. Restoration of the Constitutional Government and broadening of the power base 6. Immunities and guarantees

\footnotetext{
${ }^{159}$ The ECOWAS Commission, "Member States," < retrieved from www.ecowas.int>, May 52010.

${ }^{160}$ ECOWAS, "Economic Community of West African States Six-Month Peace Plan for Sierra Leone," October 23, 1997.
} 
After the coup in 1997 by Major Johnny Paul Koroma against the democratically elected President Ahmed Tejan Kabbah, Nigeria sent 700 troops and two naval vessels that were originally a part of the ECOMOG mission in Liberia's civil war. ${ }^{161}$ The intervention initially failed to remove Koroma from power, and successive events would lead the organization from peacekeeping mission to another faction of the war. It was not until

February 13, 1998 that ECOMOG succeeded in removing the military junta from power, and returned Sierra Leone to the hands of the elected President. ${ }^{162}$

\section{The United Nations Involvement}

In October of 1999, the UN Security Council established the United Nations Mission in Sierra Leone (UNAMSIL) as mediator to cooperate with the Sierra Leone Government and other parties, namely the RUF, in implementing the Lome Peace Accord and to assist in the implementation of the disarmament, demobilization, and reintegration of former combatants. Initially the Security Council ensured that 6,000 military personnel and 260 military observers take part in this mission. - One year later, the mandate was revised to include additional tasks. The military component was expanded to 11,000 personnel, as well as the increase in civil affairs, civilian police, and administrative and technical components. ${ }^{163}$ Three months later, in May of 2000, the Security Council increased the military personnel to 17,500 .

The UN's peace-building framework was strengthened with the creation of the Peace-building Commission in 2005. The Commission was created with the goal of creating a structure that can help countries consolidate peace, avoid relapse into conflict

${ }^{161}$ BBC News, "ECOMOG: Peacekeeper or Participant," February 11, 1998.

${ }^{162}$ Howard W. French, "Nigerians Take Capital of Freetown as Junta Flees," New York Times (February 14, 1998).

${ }^{163}$ United Nations Security Council, Resolution 1289, February 2000. 
and lay the foundations for sustainable development. ${ }^{164}$ The Peace-building Commission is mandated to "bring together all relevant actors to marshal resources and to advise on and propose integrated strategies for post-conflict peace-building and recovery; and to focus attention on the reconstruction and institution-building efforts necessary for recovery from conflict and to support the development of integrated strategies in order to lay the foundation for sustainable development."165 The Commission recognized that "as long as Sierra Leone remains susceptible to a possible resumption of violence, it is in need of sustained international attention."166

Enhancing the Interaction and Interface between Civil Society and the State to Improve People's Lives (ENCISS) is an organization that focuses on improving the boundary among state and non-state actors. ENCISS was conceived by the UK Department for International Development (DfID) and is managed by CARE Sierra Leone. One of its primary roles is to promote good governance in Sierra Leone. It began in 2005 with the view to creating a link between government and civil society for the reduction of poverty and the fulfillment of people's rights in Sierra Leone. This has been done through increasing the capacity of representatives to participate in civil society organizations, contributing to and monitoring the Poverty Reduction Strategy, and strengthening the capacity of the government of Sierra Leone to engage in constructive dialogue with civil society within specific frameworks.

\section{The Anti-Corruption Commission}

The Anti-Corruption Commission (ACC) was established by act of parliament in

\footnotetext{
${ }^{164}$ Global Witness Report, "Peacebuilding Omission," October 2007, 3.

${ }^{165}$ Global Witness, "Peacebuilding," 3.

${ }^{166}$ Global Witness, "Peacebuilding," 3.
} 
2000 to promote governmental accountability and restoring relationships with the state and the populace. The ACC is responsible for investigating alleged corruption, advising government departments and agencies on appropriate changes in their procedures and practices, educating the public and enlisting its support in the fight against corruption. ${ }^{167}$ The ACC is the result of the DFID's postwar partnership with the government. Their first National Anti-Corruption Strategy (NACS) was published in 2005 with a focus on the root causes and public perceptions, priority areas for tackling corruption and policy recommendations for reducing risk in different sectors of government. ${ }^{168}$ Initially, failure of the ACC to act on its reports resulted in a revised draft of their NACS in 2008. This draft includes statutes that are more inclusive of public perceptions of corruption. ${ }^{169}$ Similarly, in his inaugural address, Present Ernest Bai Koroma stated that "corruption is not only a matter for the leaders and heads of government institutions; it is equally a matter for everybody..." This was the main theme of his presidential campaign of "constructive nationalism."

\section{Reintegration of Combatants}

The chief problems among most organizations were the disarmament, demobilization, and reintegration (DDR) of former combatants. DDR programs were set in place prior to the war's end. ${ }^{171}$ The DDR process, which is a standard component of UN peacekeeping maneuvers, involves the peaceful disarmament of ex-combatants, the

${ }^{167}$ International Crisis Group Africa Report N 143, "Sierra Leone: A New Era of Reform," July 31 2008, 17.

${ }^{168}$ Government of Sierra Leone, "National Anti-Corruption Strategy," February 2005.

${ }^{169}$ Government of Sierra Leone, "National Anti-Corruption Strategy 2008-2013," May 2008.

${ }^{170}$ President Ernest Bai Koroma, Inaugural Address, November 152007 from ICG Africa Report, "A New Era of Reform,” 20.

171 Olonisakin, UNAMSIL, 41. 
demobilization of armed groups, and the reintegration of ex-combatants into society. ${ }^{172}$ Provisions for disarmed combatants included job training that would fit them for alternative employment, scholarships and grants to fund education, access to education at all levels made available to all combatants, and assistance to facilitate reintegration into communities. ${ }^{173}$ Vocational skills in hairdressing, tailoring, carpentry, blacksmith skills, and livestock rearing were also included in the rehabilitation and reintegration project. This training was extended to returning refugees as well. The DDR process in Sierra Leone had a total of three (3) phases, the first of which began on September 1998, and lasted until December 1998. The second phase took place from October 1999 until April 2000 ; and the third phases lasted from May 2001 until January $2002 .^{174}$

Even though there is a general consensus that DDR programs have been successful, it has also been argued that these programs fail to take into consideration an important demographic of participants in the war, whether they participated willingly or by force. The fact that females participated in the war as combatants is sometimes ignored, due to titles given to female soldiers such as "dependents," "camp followers," and "bush wives." 175 This categorization and subsequent dismissal of the holistic female experience that is based on prescribed gender roles results in the subsequent disregard of female combatants and their agency, but also their place within post-conflict policy making. As a result, female ex-combatants were not properly reintegrated into society. However,

172 Olonisakin, UNAMSIL, 54.

${ }^{173}$ ECOWAS, "Elaboration of the ECOWAS Plan," June 1997.

${ }^{174}$ United Nations Disarmament, Demobilization, and Reintegration Resource Center, Country Program: Sierra Leone, http://www.unddr.org/countryprogrammes.php?c=60\#top.

${ }^{175}$ Megan MacKenzie, "Securitization and Desecuritization: Female Soldiers and the Reconstruction of Women in Post-Conflict Sierra Leone," Security Studies (2009), 241261. 
oftentimes women and girls ex-combatants who had been subjected to rape and forced marital relations were not always welcomed into their communities, with ideas that they had not resisted enough, or the assigned identity of mothers of "rebel children."176 Without justice, recognition of the crimes or effective programs to ensure their rehabilitation, without help to rebuild their lives or steps being taken to ensure that they are protected from future crimes, the suffering of the women and girls continues. ${ }^{177}$

The presumed dichotomy between "proper" versus "traditional" becomes an issue when discussing ways to reintegrate former combatants. Researchers have put forth other methods of reintegrating ex-combatants that rely solely upon traditional--long established traits of a culture--mechanisms. Mamdani describes them as the "treasure trove of customs" in which people find conciliatory rituals and expressions that can be adapted to facilitate integration. ${ }^{178}$ These traditional forms include acceptance of ex-combatants back into the community from which they came and forgetting the past. Such rituals include cleansing ceremonies to appease the ancestors after offenses have been made, or simply forgiving those that caused violence. ${ }^{179}$ Strovel argues that while traditional forms of reintegration are acceptable and should be taken into consideration during policymaking, these "traditionalist" views lack mechanisms for building trust within a

\footnotetext{
176 Amnesty International Report, "Sierra Leone: Getting Reparation Rights for Survivors of Sexual Violence," November 1 2007, 3

${ }^{177}$ Amnesty International Report, "Getting Reparation Rights," 2007, 3.

${ }^{178}$ Mahmood Mamdani, When Victims Become Killers: Colonialism, Nativism, and the Genocide in Rwanda (Princeton: Princeton University Press 2001), 277.

${ }^{179}$ Laura Strovel, "There's no bad bush to throw away a child: tradition-inspired reintegration in postwar Sierra Leone," Journal of Modern African Studies (2008): 306.
} 
community and, therefore, are unlikely to enhance responsive forms of reconciliation. ${ }^{180}$ She further states that these traditional forms of reconciliation have a romantic and practical appeal, but can reinforce the very tensions that lead to the war in the first place. $^{181}$

On the other hand, Shaw contends that Western forms of restoration, such as the Truth and Reconciliation Commission (TRC) in Sierra Leone, are helpful for some societies, but fail to take into consideration traditional forms of resolution that already exist. She asserts that most ordinary people of Sierra Leone prefer the 'forgive and forget' approach when dealing with former combatants. ${ }^{182}$ These approaches to reform civil society are among several "formal" and "informal" programs that have been established. Other programs address national security issues that affect the citizens of Sierra Leone. Nevertheless, in the case of Sierra Leone, it can be argued that international and more traditional efforts were needed considering the failure of regional organizations such as ECOMOG in ending the violence both during and after the war's end.

The reintegration of former combatants into society was done with relative ease, due primarily to the phased approach of the program that lasted over four years. Hence, Sierra Leone's DDR program is viewed as a great success and one to which other countries experiencing a similar fate should look to as a model. Some of the recorded successes include the establishment and management of several disarmament and demobilization centers in collaboration with key implementing partners across the

${ }^{180}$ Strovel, "There's no bad bush to throw away a child," 307.

${ }^{181}$ Strovel, "There's no bad bush to throw away a child," 321.

${ }^{182}$ Rosalind Shaw, "Rethinking Truth and Reconciliation Commissions: Lessons from Sierra Leone," United States Institute of Peace Special Report (February 2005): 1-12. 
country; disarming and demobilizing over 71,000 ex-combatants; economic reintegration through the provision of vocational skills; and social reintegration measures that promoted forgiveness and reconciliation were achieved. ${ }^{183}$

Nevertheless, it has been argued that the reason for the relative ease with which factions of the war returned to wider society was that the conflict was not caused by deeply entrenched ethnic, political, or regional divisiveness, one misconception as to the root causes of the war. ${ }^{184}$ Rather, victims of violence and those pushing for peace also shared the grievances for which many combatants claimed to be fighting, namely, frustration with the government and leaders, who were seen as instrumental in nurturing the conflict. Reintegration of former combatants is significant in the immediate postwar context because it is more likely for individuals to revert to smaller scaled crimes such as petty theft and armed robbery if not reintegrated within the framework with which the programs deem appropriate. ${ }^{185}$

Nongovernmental Organizations

NGOs were established or beseeched to aid Sierra Leone during and after the war. These organizations were used to address issues pertaining to misuse of natural resources, health care for women and children, promotion of democracy, gender equality, human rights, and the rule of law; to enhancing the interaction between civil society and the state for improvement of lives.

${ }^{183}$ United Nations Office of the Special Advisor on Africa and the Government of the Republic of Sierra Leone, "Disarmament, Demobilization, and Reintegration (DDR) and Stability in Africa," Conference Report (June 2005): 22-23.

${ }^{184}$ Kieran Mitton, "Reconstructing Trust in Sierra Leone," The Round Table (August 2009), 464.

${ }^{185}$ Country Report, "Post War Reconstruction in Sierra Leone," The Courier ACP-EU, 2001, 77. 
Global witness is one such NGO that campaigns against the misuse of natural resources to fund corruption and conflict. ${ }^{186}$ Their work has recorded information pertaining to countries such as Cambodia, Democratic Republic of Congo (DRC), Liberia, Angola, and Sierra Leone. Their "voice against warlordism and corruption" led to the creation of the Kimberley Certification Process (KPCS), a project that screens the production and trade of rough diamonds. ${ }^{187}$ According to KCPS, rough diamonds is another term for uncut and unpolished diamonds, which are used to finance conflict aimed at undermining governments. ${ }^{188}$ The KPCS imposes extensive requirements on its members to enable them to certify shipments of rough diamonds as 'conflict-free' and prevent conflict diamonds from entering the legitimate trade. ${ }^{189}$ The role of Global Witness in Sierra Leone is to ensure that United Nation's Peace-building Commission integrates the need for natural resource management as part of their strategies. ${ }^{190}$ They contend that because the international community has recognized the prominent role natural resources played in sustaining the war, management is a necessity for peace.

Another international NGO is Search for Common Ground, which has its operations in various post-conflict zones across Africa. SFCG's has been involved in Sierra Leone (and the neighboring Liberia) through independent media studios, thus making media a powerful tool for peace. ${ }^{191}$ The "Talking Drum Studio" (TDS) was set up by SFCG to use media as a principal tool for peace-building and create the

\footnotetext{
${ }^{186}$ Global Witness Report, "Peacebuilding," (2007), 1.

${ }^{187}$ Global Witness Report, "Peacebuilding," 1.

${ }^{188}$ Kimberley Process Certification Scheme Document, Section I, 2003, 3.

${ }^{189}$ KPCS, Section II, 6.

${ }^{190}$ Global Witness Report, "Peacebuilding," 2.

${ }^{191}$ Lena Slachmuijlder, Unsung Heroes: Studio Ijambo in Burundi (London: Lynne Reinner Publishers, 2005), 205.
} 
opportunities for transforming conflict. The studios are comprised of teams from various ethnic backgrounds who stimulate national dialogue around critical issues through the radio broadcasts, print articles, and videos and use a "common ground" approach, while searching for appropriate solutions for all stakeholders. ${ }^{192}$ The organization's multimedia outlet became a platform for youth issues in particular. Another form of media and advocacy that was used in postwar Sierra Leone involved the international NGO WITNESS. The organization worked with local human rights advocates to film the documentary "Operation Fine Girl" to shed light and give voice to the women who were sexually terrorized during the civil war. ${ }^{193}$

Children's Learning Services (CLS) is a local NGO that was established by Emma Kamara in order to equip school-aged children with conflict resolution tools, operating on the notion that peace-building is something that is learned and thus, must be taught. ${ }^{194}$ The organization was founded in 2001, and has a threefold goal: provide quality basic education, peace-building, and nutrition security. ${ }^{195}$ This includes addressing their emotions through trauma-healing exercises. Additionally, noting that food insecurity can be a source of conflict (denial of basic needs), CLS shaped its program so as to link community food production and school feeding programs for communities that cannot afford a meal for a schoolchild.

${ }^{192}$ Slachmuijlder, Unsung Heroes, 205.

${ }^{193}$ Sam Gregory, Operation Fine Girl Exposes Sexual Violence: WITNESS in Sierra Leone (London: Lynne Reinner Publishers, 2005), 193-194, http://www.witness.org. ${ }^{194}$ Emma Kamara and Keith Neal, Food, Education, and Peacebuilding: Children's Learning Services in Sierra Leone (London: Lynne Reinner Publishers, 2005), 257-258. ${ }^{195}$ Kamara and Neal, Children's Learning Services in Sierra Leone, 258. 


\section{United Kingdom's Involvement}

Of all the countries that were members of the UN Security Council, Sierra Leone's former colonial power, the United Kingdom (UK) was the only one to demonstrate a sustained interest in the country's postwar state building process. ${ }^{196}$ It is important to mention the initial hesitancy of the World Bank in helping Sierra Leone near the end of its war. Dreher et. al. argues that membership on the United Nations Security Council (UNSC) influences the World Bank decisions on whether or not to intervene on behalf of a country as regards funding for security issues. ${ }^{197}$ The United Kingdom's involvement in Sierra Leone was largely to reform the security sector and this was predicated on their position on the UNSC.

The UK committed to help reform Sierra Leone by signing a ten-year memorandum of understanding with the Sierra Leone government committing itself to development assistance. ${ }^{198}$ Since it was the UK that provided the most aid for development programs in postwar Sierra Leone, its mission primarily addressed issues of national security within the nation. Civil society organizations worked in conjunction with the UK in reforming the security sector because cooperation between the two would contribute to the prevention of internal and external threats. ${ }^{199}$ The UK made it clear that "without establishing effective civil control over accountable and effective armed forces,

${ }^{196}$ Adebajo, Building Peace in West Africa, 80.

${ }^{197}$ Axel Dreher et al, "Development Aid and International Politics: Does Membership on the UN Security Council Influence World Bank Decisions?" Journal of Development Economics (2008): 1.

${ }^{198}$ Olonisakin, UNAMSIL, 125.

${ }^{199}$ Rosalind Hanson-Alp, "Civil Society's Role in Sierra Leone's Security Sector Reform Process Experiences from Conciliation Resources' West Africa Program," Security System Transformation in Sierra Leone (1997-2007) Working Paper Series (October 2008), 6 
long-term peace and stability would be difficult to achieve and sustain."200 During Stevens' regime, he purposefully destabilized the security sector (i.e. police force and military), thus decreasing its legitimacy and forcing members to engage in small-scale corruption. Denney contends that this particular focus of the UK was its way of tackling the cause of the war first hand. ${ }^{201}$ Some of these UK-sponsored reformation efforts include the Sierra Leone Police, Republic of Sierra Leone Armed Forces, Central Intelligence and Security Unit, Office for National Security, Public Sector Reform Unit and local government reform. ${ }^{202}$ Police reform was one of the initial priorities due to the need for internal stability and order. Family Support Units (FSUs) were established to help women and children who had been victimized by the war. Each unit was concerned with the issue of postwar domestic violence committed against bush wives who were trying to leave their husbands who were for the most part former combatants, and had forced them into involuntary marital relationships. These units provided a two-fold function of police investigation and social welfare.

The Office of National Security (ONS) was also a primary reform project of the UK. This was a necessity because one of the antecedents to the war was poor communication between the Provinces and the Capital. ONS, therefore, set up Provincial and District Security Commissions. This brought together local representatives from the military, police, fire service, immigration department, UN, and other relevant actors to

\footnotetext{
${ }^{200}$ Hanson-Alp, "Civil Society and Security Sector Reform in Sierra Leone," 2.

${ }^{201}$ Denney, "Explaining War," 160.

${ }^{202}$ Denney, "Explaining War," 158
} 
discuss security. ${ }^{203}$ The purpose of these committees is to ensure that early warning systems are in place at the grassroots level.

Justice reform came through the Justice Sector Development Program (JSDP). This sought to improve prisons through activities including refurbishing existing juvenile detention facilities and establishing new ones. Additionally, due to Sierra Leone's dual legal system, the customary legal system and the inherited British legal system, JSDP engaged in both systems because the former is the principal national provider of issues pertaining to justice and is more likely to have a larger impact on the lives of the Sierra Leonean people. ${ }^{204}$

While the UK has provided much support to Sierra Leone's postwar society, there are still major problems to be confronted by the country. One primary concern is that Sierra Leone's national budget is still largely donor dependent, meaning that the government's capacity to fund any type of assistance itself is inadequate. ${ }^{205}$ Olonisakin wrote, "The infrastructure of the country and institutions of central government had effectively collapsed during the conflict, such that the government lacked the proper capacity to address even basic needs like health and education. There was growing recognition that a failure to address some of the root causes of the conflict, such as poverty and a lack of opportunity, risked undermining the investment of the international community."206 Several years later, the country's infrastructure remains scarcely improved. An additional concern is that some of the programs are set to finish their

${ }^{203}$ Denney, "Explaining War," 159.

${ }^{205}$ Denney, "Explaining War," 160.

${ }^{206}$ Olonisakin, UNAMSIL, 125. 
course in Sierra Leone in 2010 and 2011 respectively. The fragility of peace and security and the public confidence in the police and military is still weak, although improved. ${ }^{207}$ This chapter presents some of the relevant postwar reconstruction programs and policies in Sierra Leone. It sought to examine some of these efforts to illustrate their various roles and how they fit within the context of the causes of war. The assistance of international actors was also mentioned to illustrate that the reconstruction work that has been done in regards to postwar Sierra Leone is due largely in part to the efforts of international donors. Next, an examination of a few of these postwar reconstruction programs is appraised in order to assess how well these projects have addressed the major root causes of the war. Sierra Leone and other postwar societies need to tackle the problems with its governing bodies first hand, particularly issues of corruption and funding. The problem of the gap between the government and society is part of what caused the war in Sierra Leone. This is an issue that policymakers need to deal with in order for peace to be an intrinsic part of the society for decades to come.

${ }^{207}$ Denney, "Explaining War," 159. 


\section{Chapter VI:}

\section{CONCLUSION}

In the first United Nations Peace-building Commission country-specific meeting in October 2006, the government identified four key peace-building needs where further efforts are required, both to address the root causes of the conflict and to lay the foundations for sustainable peace and development. ${ }^{208}$ They include youth employment and empowerment; justice and security sector reform; consolidation of democracy and good governance; and capacity building.

The main contention is that in order for post-conflict societies to achieve a lasting peace, efforts need to be made to address what caused the violence, and thus, prevent history from repeating itself. Indeed, we should in the conduct of human affairs at all times be influenced by the precept that history teaches us to learn from the errors of the past rather than repeat them. ${ }^{209}$ According to Lisa Denney, UK-sponsored reform efforts can be seen to have focused on issues of governance, on the basis that these issues constitute the root causes of the war. ${ }^{210}$ Recognizing the other major causes of the war as

\footnotetext{
${ }^{208}$ For additional information see the Sierra Leone Compact," The United Nations Peacebuilding Commission and the Republic of Sierra Leone Framework for Cooperation: Building on Progress" First Draft, available at:

http://www.reformtheun.org/index.php/issues/1735?theme=alt4\#developments.

${ }^{209}$ Bankole Thompson, The Constitutional History and Law of Sierra Leone (Lanham: University Press of America, Inc. 1997), 250.

${ }^{210}$ Lisa Denney, "Explaining War, Creating Peace: UK-Sponsored Reforms in Sierra Leone," Contemporary Review (Summer 2009): 153.
} 
rooted not only in governance structures, but in the deprivation of basic needs (such as health care and education) among the masses that resulted in large-scale marginalization especially among youth, opens the possibility for change.

\section{End of War}

Following the intervention of the international community, the official cessation of hostilities in Sierra Leone after a decade of war came with then President Ahmed Tejan Kabbah's declaration on January 18, 2002 that the war was finally over with the words "di war don done."211 Since then efforts have been made to ensure that the peace is sustained to enable the country to develop and rebuild communities devastated by the war. These efforts, as detailed in the previous chapter include but are not limited to, the Disarmament, Demobilization, and Reintegration (DDR) Programs, security sector reform (i.e. restructuring and legitimizing military and police), restoration of democratic governance (i.e. Presidential and Parliamentary elections), health care and educational availability for victims of war (which includes for the most part the general populace), and the Anti-Corruption Commission.

Postwar transitional elections were conducted on April $14^{\text {th }}, 2002$, soon after that came the President's declaration of the official end of the rebel war. President Kabbah was re-elected by almost a landslide, with over 70 percent of the popular vote. ${ }^{212}$ After the elections, Kabbah promised to do all in his power to alleviate the sufferings of the people. Regrettably, however, many of the specific promises have remained virtually unfulfilled, in the minds and opinions of many Sierra Leoneans, especially the youth,

\footnotetext{
${ }^{211}$ Speech by the President of Sierra Leone Ahmed Tejan Kabbah, "Address at Ceremony to Conclude the Disarmament Process," January 182002.

${ }^{212}$ International Foundation for Electoral Systems, "Sierra Leone Announces Results of Elections," May 20, 2002, http://www.electionguide.org/country-news.php?ID=192
} 
who constitute over 60 percent of the country's population. ${ }^{213}$ Successes during his administration include the improvements in security, public financial management, restoring elected local government, establishing commissions, secretariats, task forces, and committees to formulate development policy in order to manage its implementation. ${ }^{214}$ Yet, with progress in these areas comes disappointment in others. For instance, corruption at the national level was still suspected by the Sierra Leone population. $^{215}$ According to a report by the UN Secretary-General, the general consensus as to the Government's inability to deliver basic services or respond to the needs of the populace was due to corruption and mismanagement of public resources. ${ }^{216}$ Corruption, being one of the root causes of the war, provides an atmosphere of tension among the people and a sense of distrust for the government. Major promises such as jobs especially for the youth, the construction of a bridge from Freetown to Tagrin Point (a deep-water port that lies on the opposite side of the Freetown harbor) and the provision of electricity for the overcrowded capital, have remained unfulfilled. It appears as though life for the average Sierra Leonean has changed little since the end of the war.

\section{Problems of War versus Prospects for Development}

Four major themes emerged among the official documents and reports concerning the problems that led to the civil war in Sierra Leone, and postwar strategies of development. These include: alienation versus youth employment and empowerment;

${ }^{213}$ International Crisis Group Africa Report N 143, "Sierra Leone: A New Era of Reform?" July $312008,2$.

${ }^{214}$ ICG Africa Report N 143, "A New Era of Reform?” 2008, 2.

215 ICG Africa Report N 143, “A New Era of Reform?” 2.

216 "First Report of the Secretary-General on the United Nations Integrated Office in Sierra Leone [UNIOSIL]", UNSC S/2006/269, 28 April 2006, 3. 
corruption versus justice and security sector reform; leadership failure versus

consolidation of democracy and good governance; and structural collapse versus

capacity.

\section{Problems of Youth Marginalization}

As regards the problem of youth marginalization, the evidence is that little has been done to alleviate this problem because of lack of governmental resources. Youth unemployment is still rampant. This has led many youths in the Western Area to engage in street trading, as hawkers. A small number have found employment as taxi-drivers, truck drivers, mechanics, and generator technicians. ${ }^{217}$ The fact remains that although the programs that were implemented to fix the security sector were deemed a success, in addressing one cause of the war; pressing issues such as youth marginalization are still present. Because education, health and employment opportunities had been reduced to minimal standards in the years leading up to the onset of the war, the economic exclusion of youth is a widely accepted cause of the civil conflict that brutalized Sierra Leone. The Revolutionary United Front (RUF) was able to attract volunteers among the youth not because they were inclined to violence, but because they lacked social incentives and were economically and politically marginalized by the state following a widespread poverty and the failure of state institutions. However, it should be noted that a large number of these marginalized youth were drugged and forced to take up arms during the war.

One of the greatest failures of state building in Sierra Leone has been on the economic front. The UNDP Human Development Index ranks Sierra Leone 176th out of

\footnotetext{
${ }^{217}$ Sierra Leonean Official, Interview with Sierra Leonean Official, April 182010.
} 
177 countries in the world, and life expectancy in the country is only 41 years.

Development indicators for Sierra Leone are frighteningly stark with 70 percent of the population living in poverty. ${ }^{218}$ While poverty affects every part of a society, unemployed youth are especially impacted by the inability to achieve a meaningful livelihood. Three-fourths of Sierra Leone's population between the ages of 18 and 35 are unemployed, and the few who do have jobs often are not paid enough to escape the clutches of poverty. ${ }^{219}$

In light of this, it was no surprise that the rank and file of the RUF was composed mainly of urban youth who faced long-term unemployment, criminals, alienated rural youth, and young migrants working in diamond-mining districts that experienced alienation prior to the war. ${ }^{220}$ Freeman poses the question: "What is different for youth in Sierra Leone today?", and answers this by saying "very little."221 While reconstruction efforts disarmed former combatants, institutionalized a relatively stable governing structure, and expanded and reformed the police and military sectors, the average youth still does not have access to education or employment, and is subjected to injustices meted out by local chiefs, and embittered by local and high-level corruption. In the aftermath of great expectations, the youth have found themselves outside the projects that were undertaken to rebuild their country and their futures. Youth are able-bodied, but remain unskilled, jobless, and alienated. This unemployment fuels crime and conflict,

218

${ }^{219}$ Bruce Baker and Roy May, "Reconstructing Sierra Leone," Commonwealth and Comparative Politics, 42 no. 1 (March 2004): 226.

220 "Consolidating the Peace: Views from Sierra Leone and Burundi on the United Nations Peacebuilding Commission," 10.

${ }^{221}$ Christi F. Freeman, "The Failures of Post-conflict Reconstruction in Sierra Leone and the Threat to Peace," March 2008. 
which will in turn increase unemployment. The greatest threat to peace in Sierra Leone remains the state of the youth. ${ }^{222}$ The United Nations Office for West Africa (UNOWA) stated that the issue of youth marginalization and unemployment cannot be addressed on a country-by-country basis, but should include a more regional approach. ${ }^{223}$ This suggestion is not far-fetched, considering one of the causes of conflict in Sierra Leone was the spillover effect from Liberia. Nonetheless, some of the primary conditions that made the country ripe for an armed rebellion are still present, including lack of access to education and health care.

\section{Education and Health Care Reform}

Mass unemployment is still an issue in Sierra Leone. Yet government officials have said jobs cannot come if there is no peace and stability, the achievement of which they have prioritized. According to their 2009 Human Development Report, the UNDP ranked Sierra Leone 180 out of 182 on its "Health and Education Index."224 Youth and young adults, both male and female are subject to discrimination based on age. The despair was particularly acute among people over the age of 25 , because their options seemed limited. Women that are too old for school have sought skill training, farming and micro-credit schemes. ${ }^{225}$ They found that most of the programs run by NGOs were aimed at children, while profitable programs were either too costly or did not offer daycare, making it unfeasible for those with children to participate. There were plans to ensure that more children attend school, with plans to build over 500 primary and

\footnotetext{
${ }^{222}$ Freeman, "The Failures of Post-conflict Reconstruction in Sierra Leone, March 2008. ${ }^{223}$ UNOWA Issue Papers, "Youth Unemployment and Regional Insecurity in West Africa," (Dakar, Senegal: United Nations Office For West Africa, August 2006), 1. ${ }^{224}$ Human Development Report 2009, "Overcoming Barriers: Human Mobility and Development”, United Nations Development Program, 202.

${ }^{225}$ Amnesty International Report, "Getting Reparations," 2007, 14.
} 
secondary schools in the country by the end of 2007 . Very modest progress is being made in the provision of education and health care services. Again, the problem here is one of availability and adequacy of government resources. This is another sector in which much reliance is being placed on international donor resources and support. ${ }^{226}$

Gender issues particularly those of health care, education and little access to jobs have become very topical, especially among the victims of violence. While inequality based on gender was not highlighted as a cause of the war, inequality and denial of these basic needs in general was put forth as what aggrieved the population, particularly youth.

Women across Sierra Leone have expressed frustration as they discussed their desire for work and educational opportunities, and described the limited options available to them. ${ }^{227}$ The high cost of education has caused significant stress, since adult women with children (many of them survivors of rape and forced marital relations during the war) have the duty of earning enough money to send children to school, while young girls with children were at an age where schooling was still a possibility. However, although school for primary age children is free, families are expected to supply books and school uniforms, which is beyond the means of some. As a result they could not send their children to school. Secondary education school fees, ranging from 20,000 -75,000 le (US\$ 7-25) per term, were prohibitive for most families.

The high level of violence against women in Sierra Leone is a result of the state's failure to hold those accountable for rape and sexual violence during the conflict and for

${ }^{226}$ Sierra Leonean Official, Interview, April 16, 2010.

${ }^{227}$ Amnesty International Report, "Sierra Leone: Getting Reparation Rights for Survivors of Sexual Violence," November 1 2007, 13-14. 
the continuing violence against women and girls in homes and communities. ${ }^{228}$ Despite the government's obligation to protect women from rape and sexual violence, only a few steps have been taken to deal with these crimes. Amnesty International has voiced, "Failure to punish perpetrators for both past and current crimes gives the impression that they will not have to face the consequences of their actions, ignores the distress of the victims, and creates a risk of future violations.

While efforts are being made by the government through the National Commission for Social Action (NaCSA) to build health structures in rural Sierra Leone, feedback from the chiefs in several communities revealed frustration at the lack of medicine and qualified personnel. ${ }^{230}$ Organizations such as Medecins Sans Frontieres/Doctors Without Borders (MSF), which has operated in Sierra Leone since the mid-1980s, continue to highlight the poor state of the health sector and the impact this is having on the population. Although MSF has helped treat thousands of cases of malaria and through their supported health centers, in August 2007 MSF (Operational Center Amsterdam) left the country even though many of the health indicators remained very poor, indicating that not even basic healthcare needs are being adequately addressed. ${ }^{231}$ Denials of these basic needs were precursors for the war to begin with. Its presence illustrates conditions that caused the war have not been tackled effectively.

Discrimination in health care is pervasive, with women in Sierra Leone having unequal access to basic health services. Although the government adopted a policy in 2002 exempting pregnant women and other vulnerable groups from paying fees for basic

${ }^{228}$ Amnesty International Report, "Getting Reparation Rights," 2007, 14-15.

${ }^{229}$ Amnesty International Report, "Getting Reparation Rights," 2007, 13-14.

${ }^{230}$ Amnesty International Report, "Getting Reparation Rights," 2007, 13.

${ }^{231}$ International Activity Report 2007, "MSF in Sierra Leone," December 2007. 
health services, financial barriers continue to inhibit many women's access to life-saving health care. The government has failed to put systems and resources in place to implement its exemptions policy - it has not budgeted for it, has not publicized it and does not monitor its implementation. ${ }^{232}$ Women and their families are therefore charged for essential drugs, medical supplies and services that the government has stated should be free. ${ }^{233}$ Sierra Leone has one of the highest maternal mortality rates in the world, with 2,000 women out of every 100,000 dying in childbirth. There are severe problems of access to reliable health information, high rates of harmful traditional practices, and insufficient gynecological and reproductive health services available to women and girls. ${ }^{234}$ Greater emphasis should be placed on providing accurate information about women's health and the provision of services including access to primary healthcare and access to specialized health services. As of April 2010, the Government of Sierra Leone decided to supply free health care services to pregnant mothers, mothers who are breastfeeding their children, and all children under the age of five.

\section{Corruption}

To address the issue of corruption, government transparency is imperative for trust to be a fundamental part of the postwar society. The government should ensure that their audits are transparent, and disseminated in a way that enhances public understanding of operations, capacity, and limitations of governmental departments and

\footnotetext{
${ }^{232}$ Amnesty International Report, "Out of Reach: the Cost of Maternal Health In Sierra Leone," September 2009, 48.

${ }^{233}$ Amnesty International Report, "Out of Reach,” 2009, 48.

${ }^{234}$ Amnesty International Report, "Getting Reparations," 2007, 13.
} 
agencies. $^{235}$ Sierra Leone's pre-conflict government was characterized by a concentration of power among political elites and the few that were part of the masses (sometimes termed patron-client relationship). In the pre-conflict society, governmental rank was often given to a specific group of the population. Additionally, government expenditures were regionally concentrated. For success to be realized in the post-conflict society, access to government operations and positions has to be open to all groups of people, and there should be more stability along the lines of regional infrastructure. Sierra Leonean government, and other postwar societies, must tackle the problems with urgency particularly issues of corruption and funding. The problems of the breach between the government and society that is an element to what caused the war in Sierra Leone is an issue that policymakers in Sierra Leoneans need to address in order for peace to be an essential part of the society for decades to come.

According to Sierra Leonean officials, the current government has begun to address these causes in terms of adopting policies to prevent their reoccurrence. But the evidence shows that progress in this direction is slow and modest and a lot more needs to be done at a faster pace. A positive aspect, however, is that much of the effort in this area is being undertaken largely with the cooperation of the several NGOs, and other human rights agencies currently operating in the country. ${ }^{236}$

The Sierra Leone Anti-Corruption Commission is currently addressing the problem of corrupt governance. The Commission has been given new powers, chief among which is the authority to prosecute persons suspected of corrupt practices without the approval of the Attorney General and Minister of Justice. The common perception

235 ICG Africa Report N 143, "A New Era of Reform?" 2008, ii.

${ }^{236}$ Sierra Leonean Official, Interview, April 18, 2010. 
was that this factor was an impediment to the functional independence of the Commission and affected both its legitimacy and credibility. However, under its new powers the Commission has been able to prosecute some high profile cases. For example, the first Ombudsman of Sierra Leone, a prominent lawyer, was recently charged, tried, and convicted of several felonious counts involving fraudulent misappropriation of governmental funds. A former Minister of Energy and Power is currently before the High Court charged with several counts of conspiracy to defraud the Government of Sierra Leone. ${ }^{237}$ Support of the Anti-Corruption Commission is important because it plays a key role in the promotion of governmental accountability. Addressing Natural Resources

Post-conflict reconstruction and poverty reduction strategies for Sierra Leone have recognized the potential of natural resource revenue for promoting economic recovery and poverty alleviation, and programs to reform the mineral sector have been implemented. In 2007, Global Witness found evidence of a persisting pattern of youth marginalization and increasing tension due to enduring corruption and mismanagement of the mineral sector in the provinces, areas that were historically affected by the conflict. ${ }^{238}$ According to the Peace-building Commission (PBC), failure to recognize the role of natural resources in Sierra Leone's peace-building strategy from the onset could prove a dangerous oversight and undermine peace-building efforts as recognized on numerous occasions by the UN. In September 2005, the report of the UN Secretary General on the UN Mission in Sierra Leone stated that many of the root causes of the conflict, such as corruption, governance, widespread poverty, youth unemployment and the resulting

${ }^{237}$ Sierra Leonean Official, Interview, April 18, 2010.

${ }^{238}$ Global Witness, "Peacebuilding Omission?" October 2007, 7. 
public discontent, had yet to be addressed. ${ }^{239}$ The December 2005 report of the UN

Secretary General submits that the insufficient control by the government over the mining sector presented a long-term challenge that required international support long after the UN peacekeeping mission left the country. ${ }^{240}$

Truth and Reconciliation Commission (TRC)

The causes of the war in Sierra Leone were fully examined and addressed by the Sierra Leone Truth and Reconciliation Commission in their Report published in October 2004. The seven member TRC took the position that the Sierra Leone government should pay reparations to victims of the war, including, amputees, rape survivors, widows and children who suffered deprivation, displacement or worse, and other wounded victims. $^{241}$ Such actions include meeting victims' needs in health, housing, pensions, education, skills training and micro-credit, and community and symbolic reparations. This decision was made based on the assumption that these needs would restore the dignity of the victims, and would help foster conditions necessary for reconciliation.

The findings and recommendations of the Truth and Reconciliation Commission (TRC), which concluded among others that the causes of the rebel war and reparation for victims must be addressed to ensure it is not repeated, have generally not been done by the government. ${ }^{242}$ According to the WARN Policy Brief, many people are angry at the inequities that is apparent among the country's postwar society. Victims of the war are

${ }^{239}$ United Nations, " $27^{\text {th }}$ Report of Secretary General on UNAMSIL," December 12 , 2005 .

${ }^{240}$ UN Secretary General Report, December 2005.

${ }^{241}$ Sierra Leone Truth and Reconciliation Commission Report, October 2004.

${ }^{242}$ West Africa Early Warning and Early Response Network (WARN) Policy Brief, "Sierra Leone August 11, 2007 Elections: Challenges of a Transition and Beyond," 2007 www.wanep.org. 
allegedly made to live under conditions that are less than acceptable as the perpetrators are "courted by the government and let to roam about freely." 243 The government for its part has argued that it has not been able to raise the necessary funds from its international partners to fulfill all of the TRC recommendations. Moreover, the issue of dealing with former combatants is a controversial one that is influenced by the international community and its experts who handle these issues more than national governments who are always at the receiving end of policies and assistance.

While there are many causes of the conflict, both internal and external, The TRC specifically noted that weak governance structures, corruption, injustice and extreme poverty were the main causes of the war, which resulted in deplorable conditions that made conflict inevitable; there would be no lasting peace in the country without addressing these issues. ${ }^{244}$ The Commission proposed the introduction of a new, transparent regime in which citizens will have reasonable access to government information, where senior public officials disclose their financial interests and where government informs people down to the community level what amounts are being spent on services and amenities. $^{245}$

\section{Conclusion}

African states have long grappled with the need for effective institutions, responsive political processes, and responsible leaders. The problems of autocracy and difficulties of democratic development are acute. The nature of African societies poses important questions about the context of governance, and the roles of civil society. What

${ }^{243}$ WARN Policy Brief, "Challenges of Transition,” 2007.

${ }^{244}$ African Union Official Documents, "Overview of the Sierra Leone Truth and Reconciliation Report," 4.

${ }^{245}$ African Union Official Documents, "Overview of the TRC," 4. 
happened in Sierra Leone is the result of the choices made by competing political elites devoid of overarching and long-lasting national political agendas. These leaders were motivated more by the desire to acquire and maintain power than by a general commitment to parliamentary democracy and its eventual consolidation as a means of effective representative government, which was a part of the immediate postcolonial Constitution. ${ }^{246}$ It may be true that the government has failed to fulfill specific promises it made since the end of the war including the failure to fully implement the recommendations of the $\mathrm{TRC}$, as a precondition to the establishment of lasting peace in the country. The conclusions of the TRC in their 2004 Report is close to that expressed by Sierra Leoneans, that the country has returned to politics as usual in the years after the war's end. ${ }^{247}$

However, it may also be true that the government has accomplished quite a lot in the few years since the end of the war especially with regards to the rehabilitation, reintegration and reconstruction of areas and infrastructure devastated by the war. In this regard government officials are quick to refer to their successes as being directed towards the wider picture of recovery for the entire country and not merely on little things. Specifically, it is a fact that the demobilization, reintegration, and rehabilitation progress have been fifty percent successful. A significant number of ex-combatants and former rebels have returned to their places of origin, especially in the Provinces, and resumed their work as farmers, carpenters, traders, and small-scale miners. ${ }^{248}$ There is also a noticeable trend in the country towards orderly and democratic governance and a

\footnotetext{
${ }^{246}$ Peter Dumbuya, Reinventing the Colonial State: Constitutionalism, One-Party Rule, and Civil War in Sierra Leone, (iUniverse, 2008), 15.

${ }^{247}$ Sierra Leone Truth and Reconciliation Commission, "Final Report," October 2004.

${ }^{248}$ Sierra Leonean Official, Interview, April 18, 2010.
} 
reassertion of the rule of law. UNAMSIL has been wholly successful in their project. They completed their mission and have left the country. Since they left, there has not been a resurgence of any armed hostilities in the country.

While the economy is still heavily dependent on donor funds, a disproportionate share of income from diamond mining is still finding its way into private hands, rather than Government coffers. By and far, the issue that stands out the most is that of youth alienation and unemployment. UNOWA argues that advancing a culture of apprenticeship among youths is central to economic growth. ${ }^{249}$ They further suggest that although micro-finance tools and programs frequently deny youth access because they are seen as high-risk groups for credit, they should reconsider and include more youth participation because it enables self-employment, which is important in West Africa since informal activities make up a large portion of the economy. ${ }^{250}$ Nevertheless, despite reintegration programs and small-scaled jobs mentioned, thousands of ex-combatants and youths-many of whom were young children at the time of the war and never went to school-are unemployed. Even in the years after the war, civilians, particularly the younger generation, view the government as "crooked" and nothing for young people but misery. ${ }^{251}$ "Paramount" governmental promises that placed the making the youth useful and important contributors to societal development have not been realized. ${ }^{252}$ In short, the "peace" has yet to produce substantial economic surpluses and social benefits for the greater part of the population.

\footnotetext{
${ }^{249}$ UNOWA Issue Papers, "Youth Unemployment and Regional Insecurity," 25.

${ }^{250}$ UNOWA, "Youth Unemployment and Regional Insecurity," 25.

${ }^{251}$ Jonathon Clayton, "The War is Over but the Poorest of the Poor are Still Suffering," The Sunday Times (London: August 6, 2007)

252 "Hard Times in Sierra Leone: APC Bogus Promises Exposed," Standard Times Press News Sierra Leone (Freetown: May 14, 2010).
} 
In a nutshell, it is a fair and accurate judgment, given the local and national constraints existing in Sierra Leone, that the various post-conflict reconstruction programs have been, at best modestly successful. Therefore, one can predict with a certain degree of concerns that if the pace of the ongoing reconstruction programs are not hastened to meet the basic needs like educational and health care benefits for the masses, along with employment opportunities for the youth who make up the majority of the population, available, there is a possibility that Sierra Leone will relapse into another cycle of violence. Nearly fifty years after independence, the country experienced neocolonial politics that contributed to its bout with violence for over a decade. Pervasive corruption and dire failings of the government made Sierra Leone ripe for violent conflict and opened the door for conditions where the masses were at a direct disadvantage. This study illustrates that internal and external actors alike have indeed developed policies and programs. What the country is waiting for, however, is proper implementation to address these issues in order to prevent violence from reoccurring. 


\section{REFERENCES}

Abdullah, Ibrahim. June 1998. Bush Path to Destruction: The Origin and Character of the Revolutionary United Front/Sierra Leone. The Journal of Modern African Studies 36 (2): 203-235.

Adebajo, Adekeye. 2002. Building Peace in West Africa: Liberia, Sierra Leone, and Guinea-Bissau, International Peace Academy Occasional Paper Series. Boulder: Lynne Reinner Publishers.

African Union Official Documents. Overview of the Sierra Leone Truth and Reconciliation Report.

Alao, Abiodun and Comfort Ero, "Cut Short for Taking Short Cuts: The Lome Peace Agreement on Sierra Leone," Civil Wars (Autumn 2001).

Alidou, Ahmad A. Sikainga and Ousseina. 2006. Post-Conflict Reconstruction in Africa. Trenton: Africa World Press.

AllAfrica.com. June 15 2010. “Sierra Leone: Ban Lauds Country's Advances in Firming Up Stability," http://allafrica.com/stories/201006151292.html.

Amnesty International Report. November 1 2007. Sierra Leone: Getting Reparation Rights for Survivors of Sexual Violence.

- September 2009. Out of Reach: the Cost of Maternal Health in Sierra Leone.

Baker, Bruce and Roy May. March 2004. Reconstructing Sierra Leone. Commonwealth and Comparative Politics 42 (1): 35-60.

Barrows, Walter. 1976. Grassroots Politics in an African State: Integration and Development in Sierra Leone. New York: Africana Publishing Company.

BBC News. February 11 1998. ECOMOG: Peacekeeper or Participant. Great Britain.

Boas, Morten. October 2001. Liberia and Sierra Leone: Dead Ringers? The Logic of Neopatrimonial Rule. Third World Quarterly 22 (5): 697-723.

West African Early Warning and Early Response Network (WARN) Policy Brief. 2007. Sierra Leone August 11, 2007 Elections: Challenges of a Transition and Beyond. 
Campbell, Greg. 2002. Blood Diamonds: Tracing the Deadly Path of the World's Most Precious Stones. Boulder: Westview Press.

Cartwright, John R. 1978. Political Leadership in Sierra Leone. Buffalo: University of Chicago.

Chege, Michael. Summer 2002. Sierra Leone: The State that Came Back from the Dead. The Washington Quarterly 25 (3):147-160.

Clayton, Jonathon. August 6 2007. The War is Over but the Poorest of the Poor are Still Suffering. The Sunday Times.

Collier, Paul et. al. 2003. Breaking the Conflict Trap: Civil War and Development Policy Washington, D.C.: World Bank and Oxford University Press.

Compact, Sierra Leone. The United Nations Peace-building Commission and the Republic of Sierra Leone Framework for Cooperation: Building on Progress.

Consolidating the Peace: Views from Sierra Leone and Burundi on the United Nations Peace-building Commission.

Cook, Nicolas. 2003. Sierra Leone: Transition to Peace. In Sierra Leone: Current Issues and Background, edited by B. Sillinger. New York: Nova Science Publishers.

Country Report. 2001. Post War Reconstruction in Sierra Leone.

Denney, Lisa. Summer 2009. Explaining War, Creating Peace: UK-Sponsored Reforms in Sierra Leone. Contemporary Review 291 (1693): 153-161.

Dreher, Axel et. al. . January 2009. Development Aid and International Politics: Does Membership on the UN Security Council Influence World Bank Decisions? Journal of Development Economics 88 (1):1-18.

Dumbuya, Peter A. 2008. Reinventing the Colonial State: Constitutionalism, One-party Rule, and Civil War in Sierra Leone: iUniverse Inc.

ECOWAS. June 26 1997. Economic Community of West African States Six- Month Peace Plan for Sierra Leone. Conakry.

- June 1997. Elaboration of the ECOWAS Plan.

Elbadawi, Ibrahim Ahmed. 2008. Post-conflict Transitions: An Overview. The World Bank Economic Review 22 (1): 1-7.

First Report of the Secretary General on the United Nations Integrated Office in Sierra Leone [UNIOSIL]. April 282006. 
Freeman, Christi F. March 2008. The Failures of Post-Conflict Reconstruction in Sierra Leone and the Threat to Peace, Joan B. Kroc Institute for International Peace Studies, University of Notre Dame.

French, Howard W. February 14 1998. Nigerians Take Capital of Freetown as Junta Flees. New York Times.

Galtung, Johan. 1996. Peace by Peaceful Means: Peace and Conflict Development and Civilization. London: SAGE Publications.

Global Witness Report. October 2007. Peace-building Omission.

Government of Sierra Leone. February 2005. National Anti-Corruption Strategy.

—. May 2008. National Anti-Corruption Strategy 2008-2013.

Grant, J Andrew. September 2005. Diamonds, Foreign Aid, and the Uncertain Prospects for Post-Conflict Reconstruction in Sierra Leone. Round Table 94 (381):443-457.

Gregory, Sam. Operation Fine Girl Exposes Sexual Violence: WITNESS in Sierra Leone (London: Lynne Reinner Publishers, 2005). http://www.witness.org.

Hamre, John J. and Gordon R. Sullivan. "Toward Post-conflict Reconstruction," The Washington Quarterly (Autumn 2002).

Hanson-Alp, Rosalind. October 2008. Civil Society's Role in Sierra Leone's Security Sector Reform Process: Experiences from Conciliation Resources West Africa Program. In Security Sector Transformation in Sierra Leone (1997-2007) Working Paper Series.

Hard Times in Sierra Leone: APC Bogus Promises Exposed. May 14 2010. Standard Times Press News Sierra Leone.

Hinton, Samuel. 2002. University Student Protests and Political Change in Sierra Leone. Lewiston: Edwin Mellen Press, Ltd.

Hirsch, John L. 2001. Sierra Leone: Diamonds and the Struggle for Democracy, International Peace Academy Occasional Paper Series. Boulder: Lynne Reinner Publishers, Inc.

Hoeffler, Paul Collier and Anke. 2004. Greed and Grievance in Civil Wars. Oxford Economic Papers New Series 56 (4):563-595.

- February 2002. On the Incidence of Civil War In Africa. Journal of Conflict Resolution 46:13-28.

Human Development Report 2009. 2009. Overcoming Barriers: Human Mobility and Development. 
Human Rights Watch. 1999. Sierra Leone: Getting Away with Murder, Mutilation, and Rape. In Rape of Civilians. New York.

International Crisis Group. April 11 2001. Sierra Leone: Time for a New Military and Political Strategy. London.

International Crisis Group (ICG) Africa Report N 143. July 31 2008. Sierra Leone: A New Era of Reform.

ICG Africa Report N 143. November 15 2007. President Ernest Bai Koroma Inaugural Address. In Sierra Leone: A New Era of Reform.

International Foundation for Electoral Systems. Sierra Leone Announces Results of Elections May 20 2002. Available from http://www.electionguide.org/countrynews.php?ID=192.

Jaber, Hala. August 19 2007. After the Horror, the Day of Justice. The Sunday Times.

Kamara, Emma and Keith Neal. Food, Education, and Peacebuilding: Children's Learning Services in Sierra Leone (London: Lynne Reinner Publishers, 2005), 257- 258.

Kandeh, Jimmy D. April 1992. Politicization of Ethnic Studies in Sierra Leone. African Studies Review 35 (1): 81-99.

Kaplan, Robert D. February 1994. The Coming Anarchy: How Scarcity, Crime, Overpopulation and Disease are Rapidly Destroying the Social Fabric of Our Planet. Atlantic Monthly, 44-76.

Keefer, Philip. 2008. Insurgency and Credible Commitment in Autocracies and Democracies. The World Bank Economic Review 22 (1):1-29.

Keen, David. 2005. Conflict and Collusion in Sierra Leone. New York: PALGRAVE.

Kilson, Martin. 1969. Political Change in a West African State: A Study of the Modernization Process in Sierra Leone. Atheneum: Harvard University Press.

Kimberley Process Certification Scheme Document. 2003. Section I.

Kpundeh, Sahr. 2004. Corruption and Political Insurgency in Sierra Leone. In Between Democracy and Terror: the Sierra Leone Civil War, edited by I. Abdullah. Dakar: Council for the Development of Social Science Research in Africa (CODESRIA).

Krause, Jennifer Milliken and Keith. 2003. State Failure, State Collapse, and State 
Reconstruction: Concepts, Lessons, and Strategies. In State Failure, Collapse, and Reconstruction, edited by J. Milliken. Malden: Blackwell Publishing Ltd.

LeVert, Suzanne. Cultures of the World: Sierra Leone (New York: Marshall Cavendish Benchmark, 2007).

MacKenzie, Megan. 2009. Securitization and Desecuritization: Female Soldiers and the Reconstruction of Women in Post-Conflict Sierra Leone. Security Studies 18 (2): 241-261.

Maconachie, Roy and Tony Binns. Spring 2005. Going Home in Post-conflict Sierra Leone: Diamonds, agriculture and re-building rural livelihoods in the Eastern Province. Geography 90 (1): 67-78.

Mamdani, Mahmood. 2001. When Victims Become Killers: Colonialism, Nativism, and the Genocide in Rwanda. Princeton: Princeton University Press.

Miall, Hugh. August 2004. Conflict Transformation: A Multi-Dimensional Task. In Berghof Handbook For Conflict Transformation. Berlin.

Miguel, John Bellows and Edward. 2009. War and Local Collective Action in Sierra Leone. Journal of Public Economics 93: 1-45.

—. May 2006. War and Institutions: New Evidence from Sierra Leone. The American Economic Review 96 (2): 394-399.

Mitton, Kieran. August 2009. Reconstructing Trust in Sierra Leone. The Round Table 98 (403): 461-471.

Mufson, Steven. October 18 1999. U.S. Backs Amnesty in Sierra Leone. Washington Post.

Murshed, S. Mansoob. 2002. Conflict, Civil War, and Underdevelopment: An Introduction Journal of Peace Research 39 (4): 387-394.

Mustapha, Marda. 2010. Global Inequalities and Peace in Post-War Sierra Leone.

Nevin, Tom. July 2005. The Business of Conflict, The Conflict of Business. African Business (311): 21-22.

Olonisakin, Funmi. 2008. Peacekeeping in Sierra Leone: the Story of UNAMSIL. Boulder: Lynne Reinner Publishers, Inc.

Orogun, Paul. Winter 2004. Blood Diamonds and Armed Conflicts in the Post-Cold War Era. World Affairs 166 (3):151-161. 
Peterson, John. Province of Freedom: A History of Sierra Leone, 1787-1870 (Evanston: Northwestern University Press 1969).

Pham, J. Peter. 2005. The Global Dimensions of an African Civil Conflict. In Child Soldiers, Adult Interests: The Global Dimensions of the Sierra Leonean Tragedy, edited by J. P. Pham: Nova Science Publishers, Inc.

Reno, William. 2003. Political Networks in a Failing State: the Roots and Future of Violent Conflict in Sierra Leone. International Politics ad Society 2:29-43.

Revolutionary United Front of Sierra Leone. 1989. The Second Liberation of Africa.

Riley, Stephen P. 1996. Liberia and Sierra Leone: Anarchy or Peace in West Africa. In Conflict Studies 287. London.

Robert Blanton, T. David Mason, and Brian Athow. 2001. Colonial Style and PostColonial Ethnic Conflict in Africa. Journal of Peace Research 38 (4): 473-491.

Rothchild, Stuart Hill and Donald. December 1986. The Contagion of Political Conflict in Africa and the World. The Journal of Conflict Resolution 30 (4): 716-735.

Rupert, James. October 16 1999. Diamond Hunters Fuel Africa's Brutal Wars. Washington Post.

Schwarz, Rolf. 2005. Post-Conflict Peace-building: The Challenges of Security, Welfare, and Representation. Security Dialogue 36 (4): 429-446.

Shaw, Rosalind. February 2005. Rethinking Truth and Reconciliation Commissions: Lessons from Sierra Leone. In United States Institute of Peace Special Report.

Sibthorpe, A. B. C. The History of Sierra Leone (London: Frank Cass and Company Limited).

Sierra Leonean Official Interview. April 162010.

Sierra Leonean Official Interview. April 182010.

Sierra Leone Truth and Reconciliation Commission. October 2004. Final Report.

(SIPRI) Stockholm International Peace Research Institute. 1999. Yearbook of World Armaments and Disarmaments and International Security.

Slachmuijlder, Lena. Unsung Heroes: Studio Ijambo in Burundi (London: Lynne Reinner Publishers, 2005).

Speech by the President of Sierra Leone Ahmed Tejan Kabbah. January 182002. 
Address at Ceremony to Conclude the Disarmament Process. Freetown.

Strovel, Laura. 2008. There's No Bad Bush to Throw Away a Child: Tradition Inspired

Reintegration in Postwar Sierra Leone. Journal of Modern African Studies 46 (2): 305-324.

Sullivan, John J. Hamre and Gordon R. Autumn 2002. Toward Post-Conflict Reconstruction. The Washington Quarterly 25 (4): 85-96.

Tarr, Byron. June 2008. Orientations and Challenges of Economic and Social Reconstruction in Sierra Leone and Liberia. In Regional Workshop on PostConflict Development. Abidjan, Cote d'Ivoire: Sahel and West Africa Club \& Economic Community of West African States (ECOWAS).

The ECOWAS Commission. 2010. Member States [cited May 5 2010].

Thompson, Bankole. 1997. The Constitutional History and Law of Sierra Leone. Lanham: University Press of America, Inc.

Truth and Reconciliation Commission for Sierra Leone. October 2004. Final Report. United Nations. December 12 2005. 27th Report of Secretary General on UNAMSIL.

- October 18 1998. Second Progress Report of the Secretary General on the United Nations Observer Mission in Sierra Leone.

United Nations Security Council. February 2000. Resolution 1289.

UNOWA Issue Papers. August 2006. Youth Unemployment and Regional Insecurity in West Africa. Dakar.

- August 2006. Youth Unemployment and Regional Insecurity in West Africa. Dakar.

Uvin, Peter. 2009. Life After Violence: A People's Story of Burundi, African Arguments. New York: Zed Books.

Verkoren, Willem and Gerd Junne. 2005. Post Conflict Development: Meeting New Challenges. Boulder: Lynne Reinner Publishers.

Vick, Karl. October 19 1999. Albright Meets With Sierra Leone Rebels. Washington Post. 


\section{CURRICULUM VITAE}

NAME: Lovetta Anita Thompson

ADDRESS: 541 Paso Fino Drive

Richmond, KY 40475

DOB: $\quad$ Freetown, Sierra Leone - February 20, 1985

\section{EDUCATION}

\& TRAINING: MA: Pan-African Studies (expected December 2010)

Concentration: Postwar Reconstruction

Major Advisor: Raphael Chijioke Njoku

University of Louisville, Louisville, KY

B.A., English

University of Kentucky

2003-2007

AWARDS: William C. Parker Scholarship

University of Kentucky, Lexington, KY

2004, 2005, 2006

Graduate Assistantship, Department of Pan-African Studies

University of Louisville, Louisville, KY

2008, 2009

Dr. Folasade Iyun Award for Outstanding Achievement as a Graduate Student in the Department of Pan-African Studies

University of Louisville, Louisville, KY

2010

Acceptance and Participation in Caux Scholars Program in International Peace and Conflict Resolution

Caux, Switzerland

2010 
NATIONAL

MEETING

PRESENTATIONS: Thompson, L. (2009, March). Third World Armed Conflict: the Manifestation of Colonialism in Postcolonial Africa. Paper presented at the National Council for Black Studies Conference, Atlanta, GA

Thompson, L. (2009, April). The Multidimensional Roles of African

Women in War. Paper presented at the Southern Interdisciplinary

Roundtable on African Studies Conference, Frankfort, KY 